
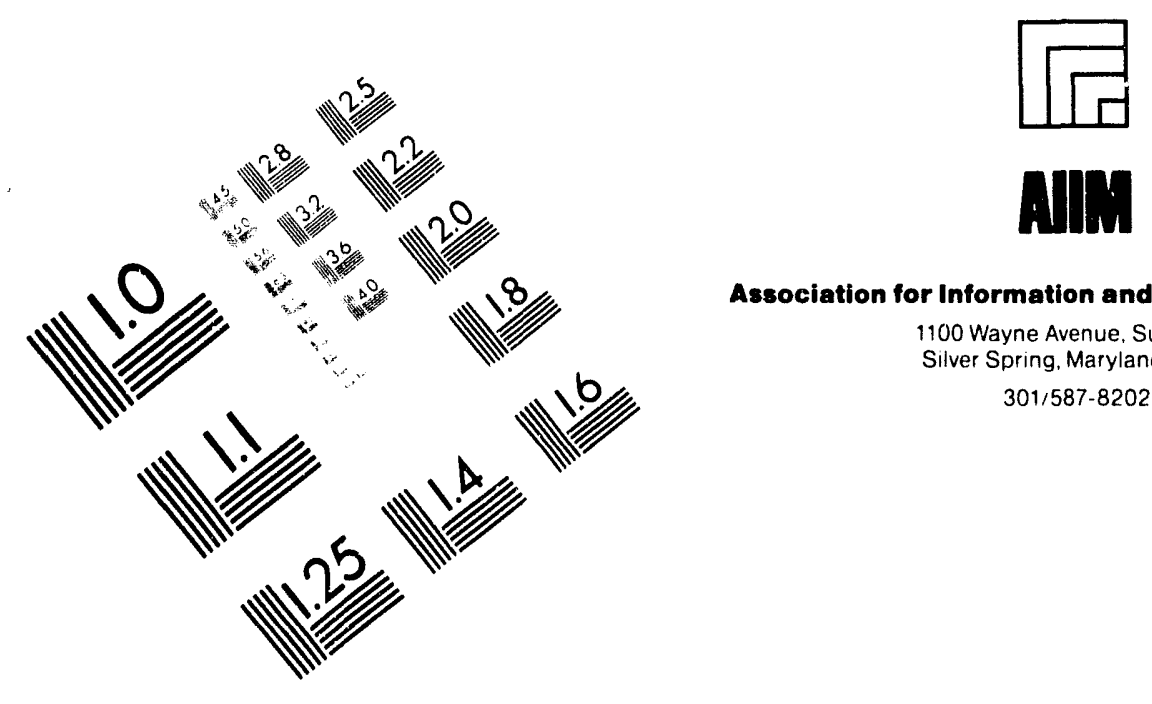

Association for Information and Image Management

1100 Wayne Avenue, Suite 1100

Silver Spring. Maryland 20910

301/587-8202

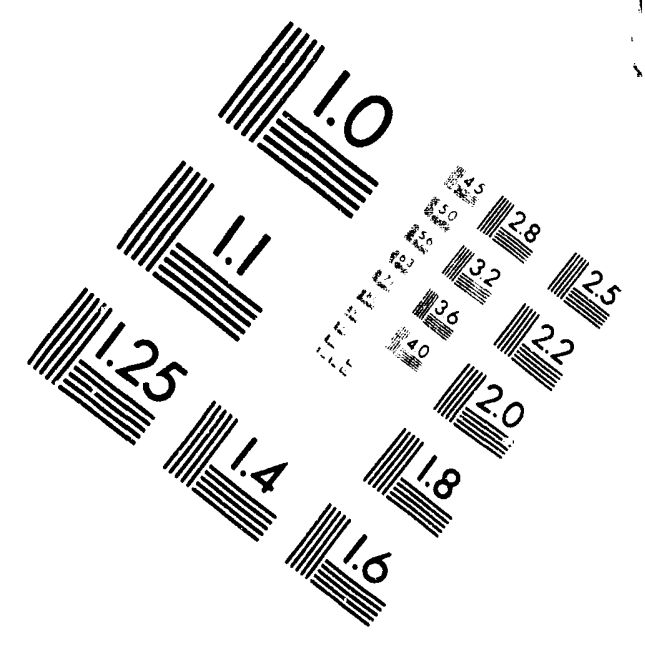

\title{
Centimeter
}

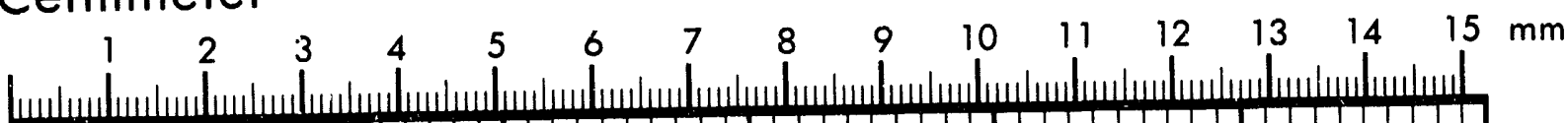

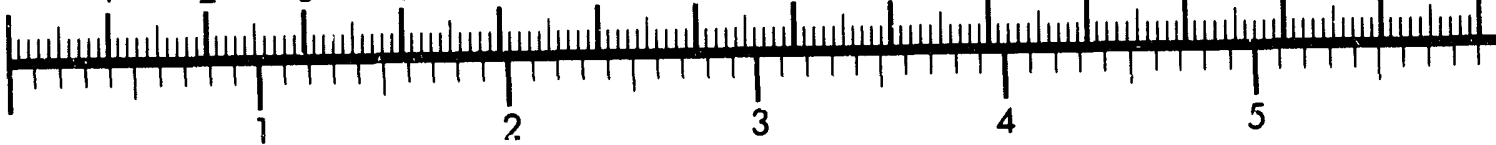
Inches
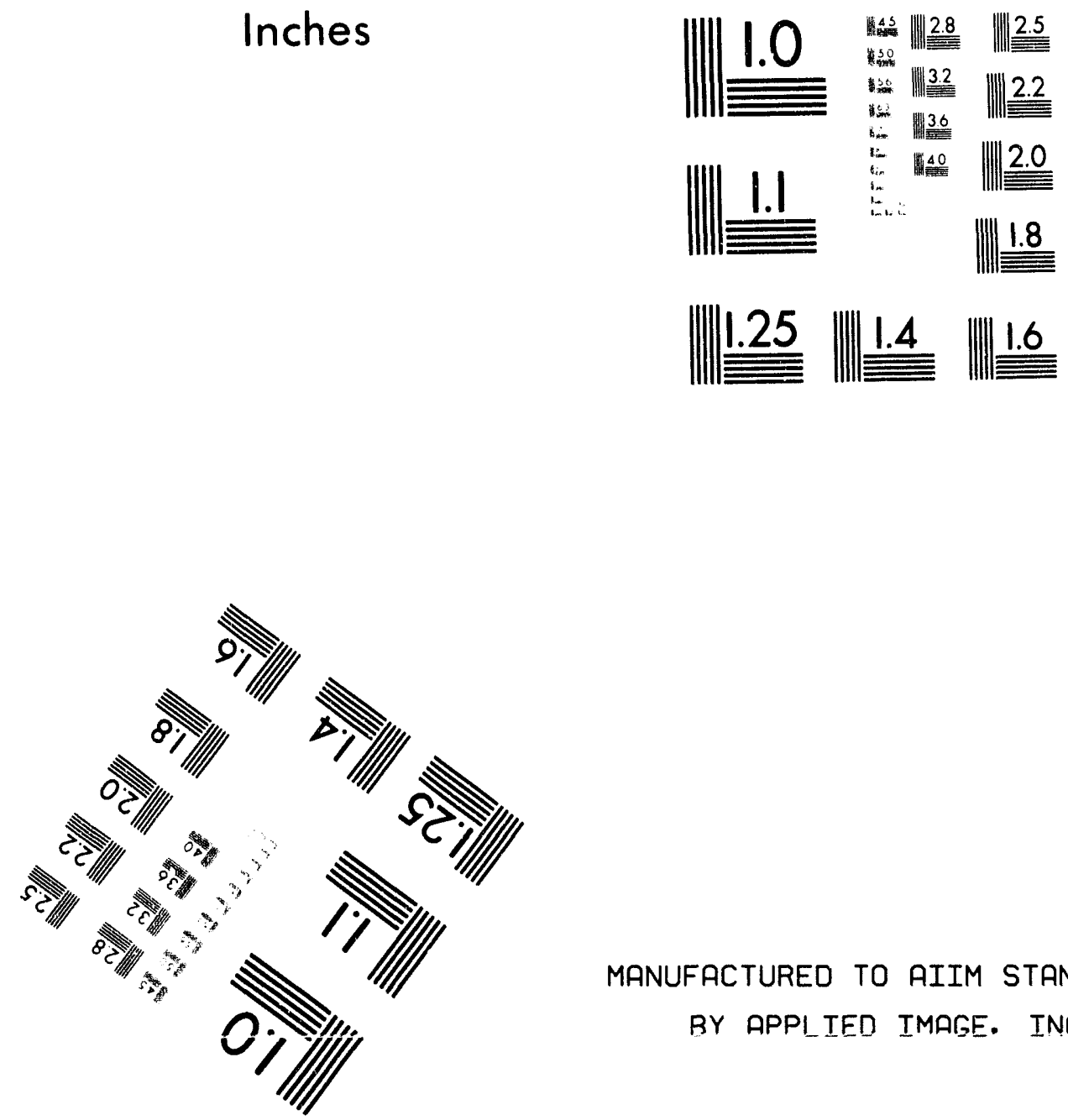

MANUFACTURED TO AIIM STANDARDS

BY APPLIED IMAGE. INC,

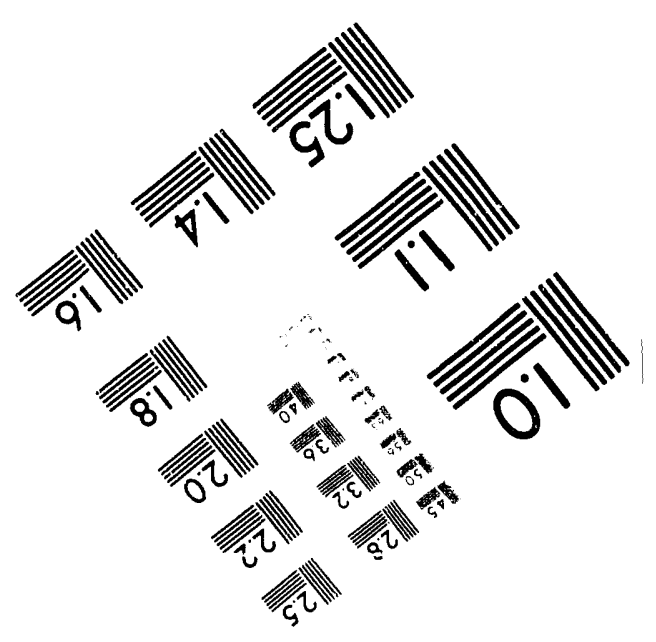



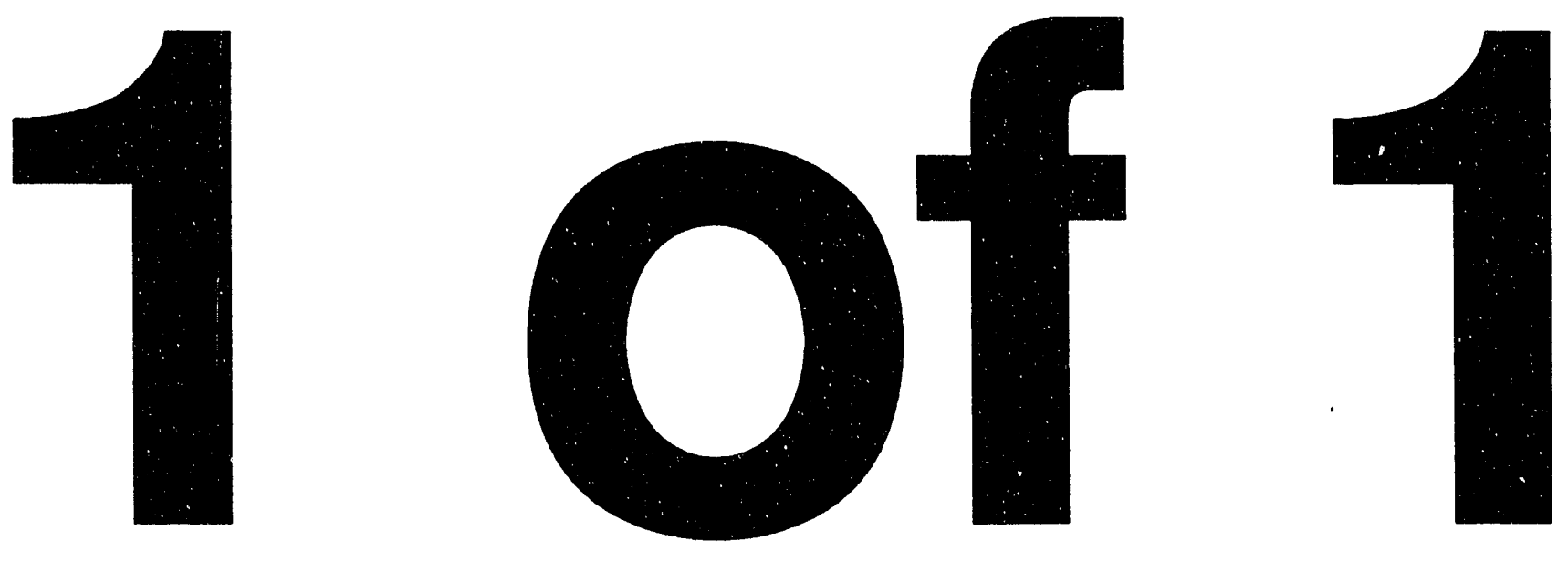


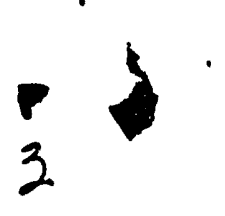

FINAL VERSION

PINAL REPORT

\section{LIFE ASSESSMENT AND EMISSIONS MONITORING \\ OF INDIAN COAL-FIRED POWER PLANTS}

PREPARED BY:

TENNESSEE VALLEY AUTHORITY

\section{DISCLAIMER}

JULY 1992

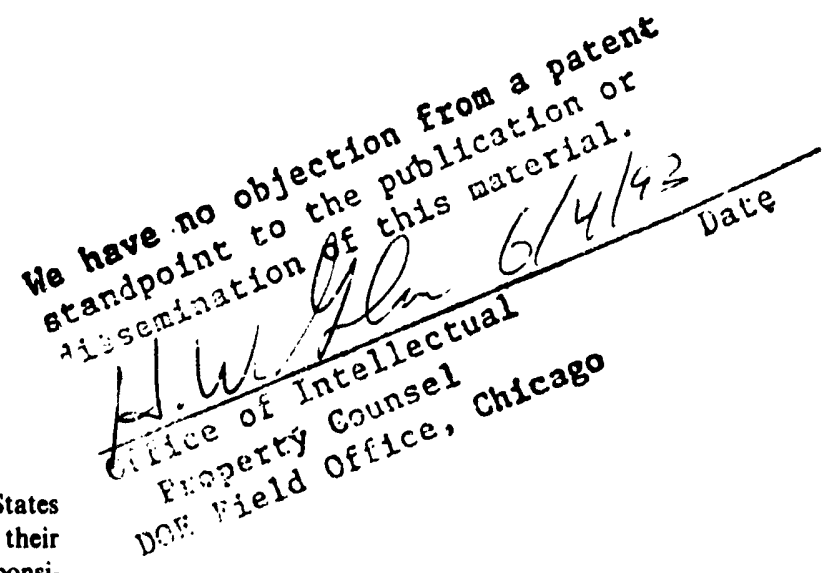

This report was prepared as an account of work sponsored by an agency of the United States employees, makes any warranty, express or implied, or assumes any legal liability or responsibility for the accuracy, completeness, or usefulness of any information, apparatus, product, or process disclosed, or represents that its use would not infringe privately owned rights. Reference herein to any specific commercial product, process, or service by trade name, trademark, manufacturer, or otherwise does not necessarily constitute or imply its endorsement, recommendation, or favoring by the United States Government or any agency thereof. The views and opinions of authors expressed herein do not necessarily state or reflect those of the United States Government or any agency thereof.

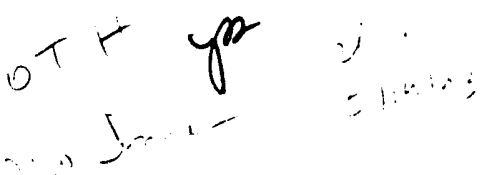




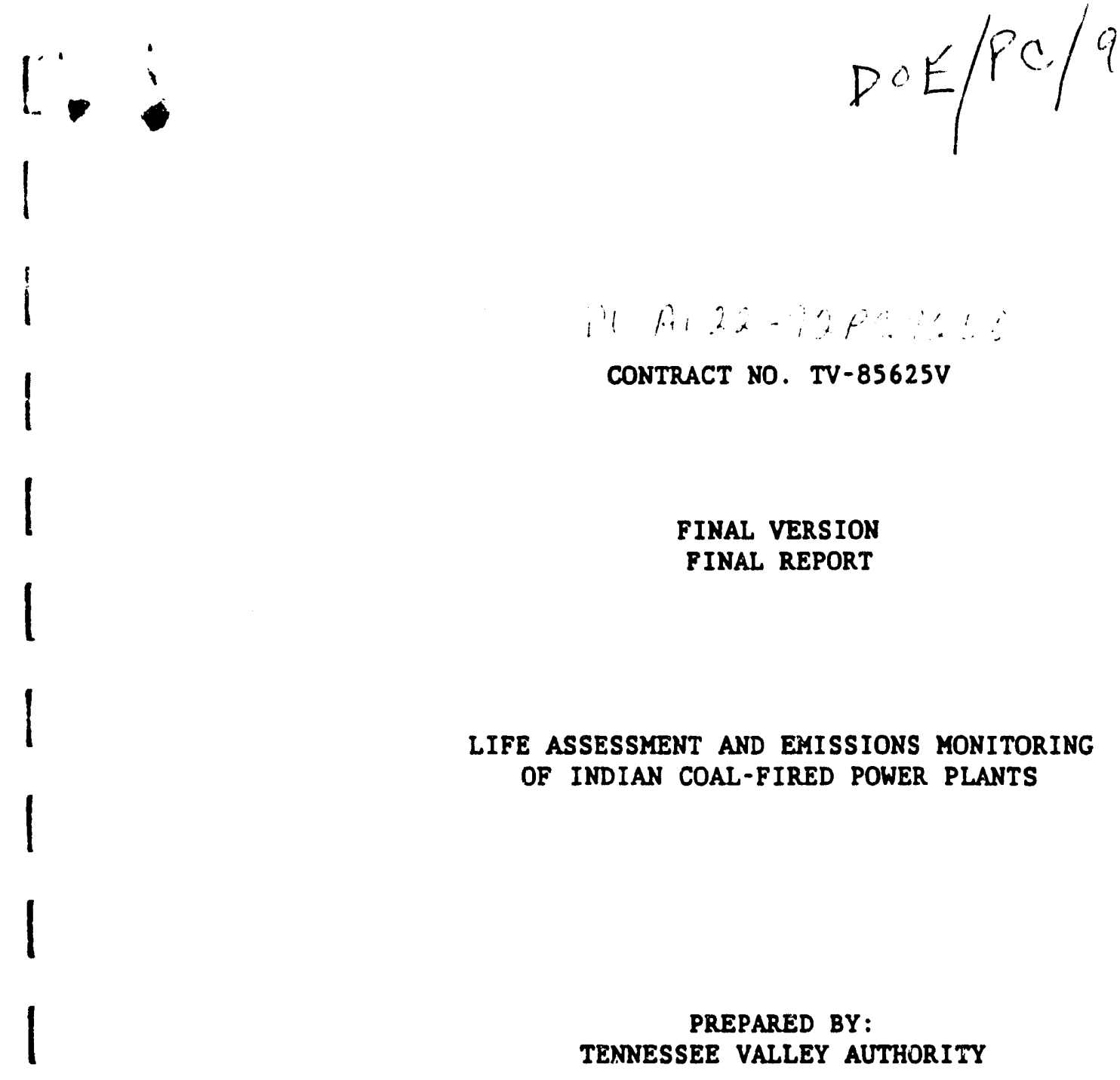

$D \circ E / P C / 92580 \cdots T$

FINAL VERSION

PINAL REPORT

IFE ASSESSMENT AND EMISSIONS MONITORING

OF INDIAN COAL-FIRED POWER PLANTS

TENNESSEE VALLEY AUTHORITY

JULY 1992 
TVA CONTRACT NO. TV-85625V

TABLE OF CONTENTS

\section{IITLE}

Environmental Emissions Monitoring Purpose

Executive Summary

01

Travel Summary

01

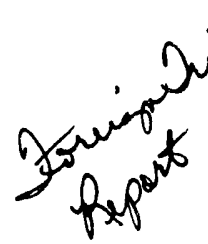

02

02

Bangalore 02

Trichy 02

Vi jawayada 03

Conclusions - Testing 03

Test Matrix 04

Data 04

Results 05

Recommendations 06

Acknowledgements $\quad 08$

Appendix A

Travel Itinerary 09

Appendix B

Introduction 10

Objectives 10

Scope 11

Results 11

Analyzers $\quad 15$

Conclusions $\quad 17$

Appendix C

Test Matrix 18

Test Data 19

Graphics 32

Appendix D

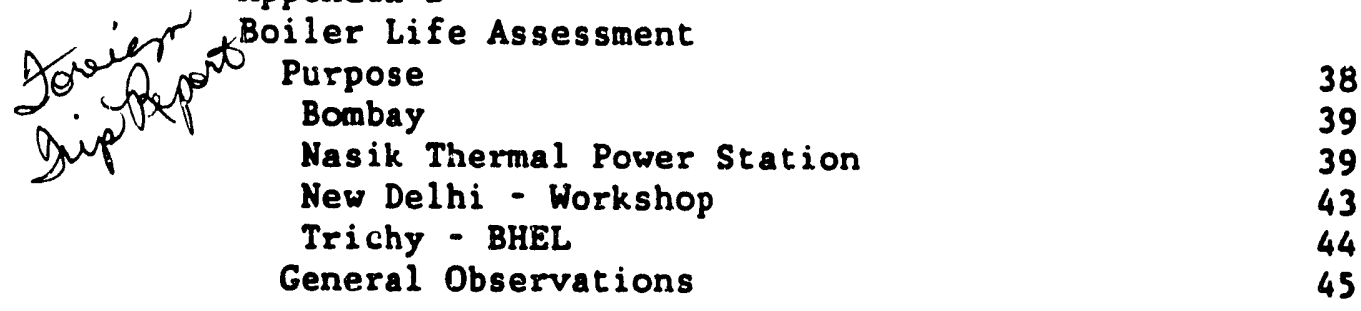

Attachment 1.

Results Summary 46

Boiler Drum $\quad 46$

Furnace $\quad 46$

Economizer $\quad 46$ 
Primary Superheater

Radiant Superheater

47

Convection Superheater

47

Reheater

47

Reheat At temperator

48

Main Steam Attemperator 48

Piping

48

Attachment 2 .

Workshop Agenda

At tachment 3 .

Workshop Attendees

Appendix E

Strategy Planning $\quad 56$

Purpose $\quad 56$

Executive Sumnary $\quad 56$

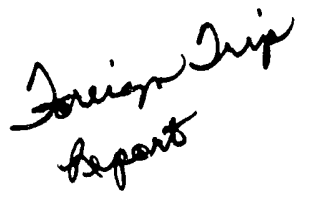

Travel Summary

PFC and NTPC

PFC

56

59

USAID

59

PFC

60

Lurgi AG

60

Conclusions

60 
TRIP REPORT OF PHILLIP D. TINGLE, TENNESSEE VALLEY AUTHORITY,

CHATTANOOGA. TENNESSEE, TO INDIA

JANUARY 23 - FEBRUARY 15,1992

Purpose:

The traveler undertook a 3-week trip to India beginning January 23, 1992 to plan and conduct an environmental emissions monitoring program at a coal-fired utility with Bharat Heavy Electricals Limited (BHEL), Trichy, India, and the Central Power Research Institute (CPRI), Bangalore, India.

Executive

Summary:

At the request of the Pittsburgh Energy Technology Center (PETC) of the United States Department of Energy (USDOE), the traveler, along with Dr. R. P. Krishnan, Oak Ridge National Laboratory (ORNL), Oak Ridge, Tennessee, spent three weeks in India planning and performing emissions monitoring at the coal-fired Vijayawada Thermal Power Station (VTPS). The coordination for the Indian participants was provided by BHEL, Trichy and CPRI, Bangalore. The trip was sponsored by the PETC under the United States Agency for International Development (USAID)/Government of India (GOI), Alternate Energy Resources Development (AERD) Project. The AERD Project is managed by PETC, and ORNL is providing the technical coordination and support for four coal projects that are being implemented with BHEL, Trichy.

The traveler, after briefing the USAID mission in New Delhi, visited BHEL, Trichy and CPRI, Bangalore to coordinate and plan the emissions test program. The site selection was made by BHEL, CPRI, TVA, and PETC. Monitoring was performed for 4 days on one of the 4 existing $210 \mathrm{MW}$ coal-fired boilers at the VTPS, $400 \mathrm{~km}$ north of Madras, India. 
Travel

Summary:

1. Meetings with USAID, New Delhi

The traveler briefed Mr. N. V. Seshadri and Dr. John Grayzel,USAID, on January 28, 1992, on the planned site activities. The equipment and procedures for the testing were discussed and reviewed with the Mission staff. Dr. R. P. Krishnan, ORNL, made a detailed presentation to the Mission staff on the status of the AERD coal projects and, in particular, the site activities on two of the projects which concerned ( 1 ) environnental monitoring and (2) life assessment of power plant components.

2. Meetings with CPRI, Bangalore

On January 31 -February 1 , a visit was made to CPRI, Bangalore where the traveler met with management and staff and toured the facilities. During a brief meeting with the Director General, Dr. M. Ramamoorty, and Joint Director, Mr. K. R. Krishnasvamy, the proposed site activities were discussed. Also, CPRI requested information in several areas of interest on projects proposed or performed in the United states. Those requesting information and the topics of concern were:

Mr. B. H. Narayana, TVA's experiences with the Westinghouse Solid Oxide Fuel Cell.

Dr. B. K. Chaturvedi, Zero Discharge Water Systems in Power Plants.

Mr. Nagaraja Rao, Amide/Amine-Based Poly Electrolytes For Water and Waste Water Treatment.

3. Meetings with BHEL, Trichy

February 2-5, was spent at BHEL where the traveler met with the management and staff of Research \& Development. Several meetings were held to discuss and coordinate the testing to be performed at the VTPS, plan the test matrix, and determine the best site location for conducting the test. A detailed presentation on TVA's background and experiences in emissions monitoring, building a database, equipment needed, methodologies, approach, and results of our endeavor to meet the Cixan Air Act requirements for the United States was made to about 80 BHEL employees.

A tour of the BHEL test facilities was also provided during this visit. 
Mr. A. V. Narayanan, General Manager, BHEL also requested information on municipal waste and municipal waste pellet technology with the capability to handle 500K tons of waste per day.

4. Visit to VTPS, Vijayawada

February 6-10, was spent at the VTPS where the emissions monitoring test was performed. Part of the first day was spent touring the facilities and meeting the management and staff.

A discussion on the test program is included in this report under the title of "Conclusions."

\section{Conclusions:}

Testing:

The emissions monitoring was performed on unit 1 at the VTPS. The traveler, along with Mr. K. Chandrasekaran, BHEL, and Mr. Nagaraja Rao, CPRI, performed the monitoring. TVA, BHEL, and CPRI provided the test equipment. The gaseous sample was extracted from the duct at the electrostatic precipitator (ESP) outlet up stream of the induced draft fans. It was routed through a sample conditioning system and then to each analyzer. The gas sample was analyzed for $\mathrm{NOx}, \mathrm{SO}_{2}, \mathrm{CO}$, and $\mathrm{O}_{2}$. Coal samples from the feeders, bottom ash samples, and ash samples from the ESP hoppers were taken during each test. Coal fineness testing was performed one time during the test program.

A complete report on the testing is included as appendix B to this report. Highlights from the report are as follows:

A total of 12 tests were performed during the 4-day period. Six tests were run with the air dampers, which are identified as (F FF) by BHEL, closed while varying the excess air and the fuel-air damper (FAD) position. Another 6 tests were run with the air dampers opened, simulating over-fire air (OFA) conditions while varying the excess air and the fuel-air damper position. There were two positions for the fuel-air dampers, the normal position of 20 percent open and the test condition of 5 percent open. The excess air was varied from 15 percent to 25 percent. 
Test

Matrix:

$\begin{array}{cllr}\text { TEST } & \text { F \& FF } & \text { EXCESS } & \text { FAD } \\ \text { NO } & \text { DAMPERS } & \text { AIR } & \text { OPEN } \\ 01 & \text { CLOSED } & 20 \% & 20 \% \text { (TYPICAL) } \\ 02 & \text { CLOSED } & 20 \% & 5 \% \\ 03 & \text { CLOSED } & 25 \% & 20 \% \\ 04 & \text { CLOSED } & 25 \% & 5 \% \\ 05 & \text { CLOSED } & 15 \% & 20 \% \\ 06 & \text { CLOSED } & 15 \% & 5 \% \\ 07 & & & \\ 08 & \text { OPEN } & 20 \% & 20 \% \\ 09 & \text { OPEN } & 20 \% & 5 \% \\ 10 & \text { OPEN } & 25 \% & 20 \% \\ 11 & \text { OPEN } & 25 \% & 5 \% \\ 12 & \text { OPEN } & 15 \% & 20 \% \\ & \text { OPEN } & 15 \% & 5 \%\end{array}$

Data :

The data presented in this report should not be accepted as absolute values for emissions from Indian coal plants.

However, the data does follow expected trends for reduction in $\mathrm{NO}_{x}$ emissions when simulating an OFA condition and for characterizing the $\mathrm{NO}_{x}$ sensitivity to excess air and load reductions. The accuracy of the values reported is questionable due to the lack of adequate calibration before and during the testing. Apparently procuring large amounts of calibration gas in India is a problem, not only due to the lack of suppliers but also to the quality or accuracy of the concentrations of the gases. If India is going to initiate an emissions monitoring program, they must first address this problem to ensure the accuracy of the data generated. This is a severe problem since it could render the data generated meaningless.

Several other problems associated with the analyzers transported to India by TVA and PETC contributed to the matter of questionable accuracy. The Beckman $\mathrm{SO}_{2}$ analyzer failed, the Fuji CO analyzer worked properly, but there was not enough calibration gas to adequately calibrate it. The portable Land Combustion analyzer, carried as a back-up, failed also. The other analyzers performed well, but some could not be calibrated of ten enough while others were not EPA-approved because they are electrochemical-cell-type portables. This does not mean that they are not accurate, but only that they are not EPA-approved methods. If additional testing is performed in India, approved analyzers must be made available in India. 
The VTPS data was taken utilizing the following instrumentation:

$\begin{array}{lcl}\text { Analyzer } & \text { Constituent } & \text { Owner } \\ \text { Shimadzu } & \mathrm{NO}_{x} & \\ \text { Teledyne } & \mathrm{O}_{2} & \text { CPRI } \\ \text { LandCom } & \mathrm{CO} & \text { TVA } \\ \text { LandCom } & \mathrm{SO}_{2} & \text { BHEL } \\ \text { SCS } & & \text { BHEL } \\ \text { Probe } & & \text { TVA } \\ & & \text { TVA }\end{array}$

* Sample Conditioning System

Results:

At typical unit operating conditions, $200 \mathrm{MW}$ and 20 percent excess air, the $\mathrm{NO}_{x}$ averaged $309 \mathrm{ppm}$ corrected to 3 percent $\mathrm{O}_{2}$ or $0.42 \mathrm{lbs} / \mathrm{MBtu}$. The $\mathrm{SO}_{2}$ averaged $395 \mathrm{ppm}$ (actual conditions) or $0.96 \mathrm{lbs} / \mathrm{MBtu}$. When the OFA simulation test was performed (test 07 ), the $\mathrm{NO}_{x}$ averaged $185 \mathrm{ppm}$ corrected to 3 percent $\mathrm{O}_{2}$ or $0.25 \mathrm{lbs} / \mathrm{MBtu}$. The magnitude of the reduction of $\mathrm{NO}_{x}$ during the OFA simulation was greater than expected. Typically, OFA will result in only approximately 20-25 percent reduction. In this case, it was about 40 percent, which is not in line with data taken at TVA plants. As stated above the data may not reflect the actual values for emissions.

In all cases, closing the FADs to 5 percent open resulted in a decrease in $\mathrm{NO}_{x}$ emissions. Typically, when evaluating control techniques expected to affect $\mathrm{NO}_{x}$ formation, the FADs are left in the 100 percent open position. However, BHEL preferred to change the settings for this evaluation. This configuration needs to be evaluated with respect to unit operating conditions such as flame stability, flame length, and combustibles in the ash before drawing any conclusions. There is a possibility that this configuration has a quenching effect on the flame, thereby lowering the temperature and decreasing the thermal $\mathrm{NO}_{x}$ formation, or it may delay the devolatilization of the coal during the combustion process. Additional testing would be required to evaluate the effects of this mode of operation.

In all but one case, increasing excess air increased $\mathrm{NO}_{x}$ emissions, as would be expected, while decreasing excess air decreased $\mathrm{NO}_{x}$ emissions. 
No attempt was made to characterize $\mathrm{NO}_{\mathbf{x}}$ reduction versus boiler load since changing the damper settings and percent excess air during the testing complicates the analysis. However, the data indicate that $\mathrm{NO}_{x}$ emissions decrease as the boiler load decreases.

The $\mathrm{SO}_{2}$ emissions ranged from 0.92 lbs/MBtu to 1.37 lbs MBtu. However since all of this data was taken with the cell-type analyzer, additional testing should be performed using ultraviolet absorption methods before drawing any conclusions.

The carbon monoxide ( $C O$ ) emissions followed the expected trend, i.e., increasing excess air reduces $C O$ emissions. The CO emissions were somewhat higher than the typical emissions at TVA.

Overall, the test program was very successful. It was a learning process for all parties involved, and any future exchange programs will benefit from the lessons learned during this program.

To determine actual baseline gaseous emissions at the Indian plants and have confidence in the resulting data, the testing should be performed using approved techniques and analyzers for all flue gas constituents. Although it was the intent of this program to do just that, problems with the transported equipment prevented approved $\mathrm{SO}_{2}$ and $\mathrm{CO}$ measurements. A list of equipment meeting EPA requirements is included in Appendix $B$ of this report. This is only meant to be an example of the approved principles of operation and is not an endorsement by TVA for any vendor or product. However, these analyzers are currently being used by TVA in the R\&D extractive system.

Recommendations:

The management and staff at VTPS are doing an excellent job of operating and maintaining the facilities and are to be commended on the cleanliness and appearance of the plant.

CPRI and BHEL Research Development employees are very knowledgeable in the areas of emissions testing and vould benefit greatly from additional training in the United States on state-of-the-art equipment and methods. 
TVA, through its progressive environmental leadership in the U.S., is in a position to make a significant contribution to BHEL or other Indian companies involved in power production. Contributions could be made through an exchange of information or by providing training in the areas of methodologies, techniques, and equipment selection needed to conduct environmental monitoring in India. A total of five days during this test program was spent clearing the equipment through Indian Customs. If TVA's participation involves more than an information exchange program, problems associated with Customs' procedures and availability of essential equipment and calibration gases necessary to conduct testing programs must be addressed by the Indian Government. 


\section{ACKNOWLEDEMENTS}

TVA would like to express its gratitude for the belp and cooperation of BHEL and CPRI personnel throughout the test program. In particular, Mr. V. Gopalakrishnan, Mr. K.

Chandrasekaran, and Mr. Abdul Salam of BHEL and Mr. Nagaraja Rao, CPRI. Also Dr. R. P. Krishnan, ORNL, for his

assistance and coordination of the overall program in India.

APPENDIX A 
IRIP REPORT

PHILLIP D. TINGLE

INDIA, JANUARY-FEBRUARY 1992

\section{Itinerary:}

Date

January 23-25

January 28

January 28-30

January 31-February 1

February 2-5

February - 6-10

Pebruary 11-13

February 14-15
Event

Travel to New Delhi, India Meeting with USAID New Delhi Clearing Customs at Madras Meeting with CPRI Bangalore Meeting with BHEL Trichy Emissions Monitoring at VTPS Clearing Customs at Madras Travel to United States 


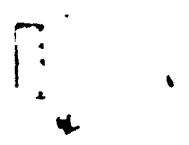

APPENDIX B<smiles>[CH]</smiles>

I

1

I<smiles>[CH]</smiles><smiles>[CH]</smiles><smiles>[CH]</smiles><smiles>[CH]</smiles><smiles>[Tl]</smiles><smiles>[CH]</smiles><smiles>[Tl]</smiles><smiles>[CH]C</smiles>

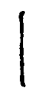

$$
1
$$


CONTRACT TV-85625

PITTSBURGH ENERGY TECHNOLOGY CENTER

U. S. DEPARTMENT OF ENERGY

EMISSIONS MONITORING AT THE

VIJAYAWADA THERMAL POWER STATION

VIJAYAWADA, INDIA

FEBRUARY 1,992

APPROVED BY: $\frac{6.0 \text { E. David Daugherty }}{\text { MANAGER, RESEARCH \& DEVELOPMENT }}$

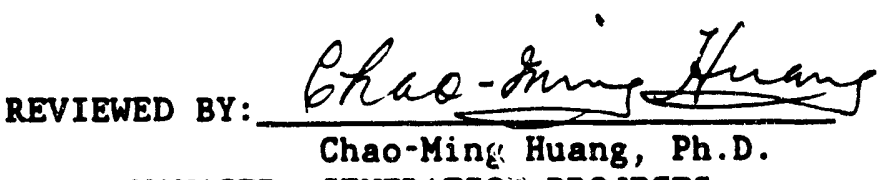

MANAGER, GENERATION PROJECTS

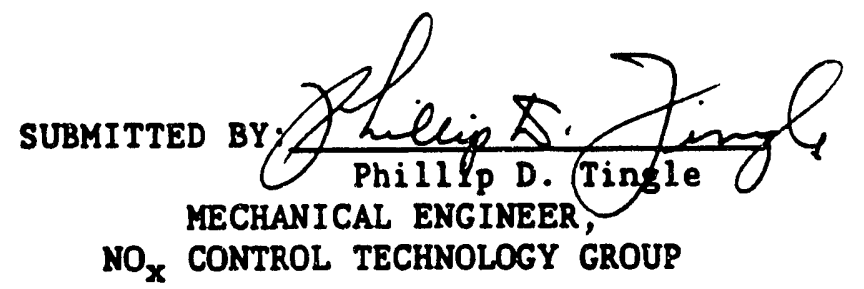

TEMNESSEE VALLEY AUTHORITY

CHATTANOOGA, TENNESSEE

37402 
This report was prepared by the Tennessee Valley Authority (TVA) as an account of work performed for the United States Department of Energy (USDOE)/Pittsburgh Energy Technology Center (PETC) and co-sponsored by the United States Agency for International Development and the Government of India. Neither TVA, PETC, nor any person acting on their behalf: (a) makes any warranty or reptresentation, express or implied, as to the accuracy, completeness, usefulness or reliability of any information, apparatus, product, method, or process discussed in this report; (b) assumes any liability or responsibility with respect to the use of, or for damages resulting from the use of, any information, apparatus, product, method, or process discussed in this report; or (c) represents that the use of any information, apparatus, product, method, or process discussed in this report would not infringe privately owned rights.

Reference herein to any specific comercial product, process method, or service by trade name, trademark, manufacturer, or otherwise does not constitute or imply an endorsement or recommendation by TVA, PETC, or any person acting on their behalf. The views and opinions of the author expressed herein do not necessarily state or reflect those of TVA or PETC. 


\author{
EMISSIONS MONITORING AT THE \\ VIJAYAWADA THERMAL POWER STATION \\ VIJAYAWADA, INDIA \\ FEBRUARY, 1992
}

1.0 Introduction:

An Interagency Agreement between the Tennessee Valley Authority (TVA) and the U.S. Department Of Energy (DOE) provides for TVA's participation in a project entitled "Life-Assessment and Environmental Emissions Monitoring of Indian Coal-Fired Power Plants." The project is being sponsored by the U.S. Agency for International Development (USAID) and the Bharat Heavy Electricals Limited (BHEL) of Trichy, India, under the Participating Agency Service Agreement (PASA) No. ANE-0474-P-EK-9019-00 between DOE and USAID. TVA and BHEL will collaborate and exchange information on methodologies, techniques, and supporting R\&D required for detailed technical assessment of remaining useful life of coal-fired power plants in India and perform baseline emissions monitoring of $\mathrm{MO}_{x}$ and $\mathrm{SO}_{2}$ from a coal-fired plant. TVA sent engineers to India to assist in the above activities in January. This agreement also permits BHEL to send engineers to TVA's Research and Development (R\&D) facilities and plants to learn from the operating experiences of TVA.

This report discusses the initial emissions monitoring portion of the agreement.

2.0 Objective:

The objective of this trip was to measure emissions from an Indian coal-fired power plant using state-of-the-art techniques. This information would becone part of a database to be developed by the utilities in India. Although the agreement is much larger in scope, it was decided that due to a limited equipment budget and the problems in transporting equipment to India from the U.S., the initial visit would be "best effort" to measure emissions and determine what problems are associated with conducting a project of this scope in India. 
3.0 Scope:

TVA and PETC will provide three emissions analyzers and the sample conditioning system. BHEL and the Central Power Research Institute (CPRI), Bangalore, India, will provide one analyzer each.

The testing will include in-furnace control strategies such as over-fire-air (OFA) simulation, burners out of service, and variations in excess air to quantify emissions for database purposes.

The Vijayawada Thermal Power Station (VTPS), Vijayawada, India was selected as the test site for performing the emissions monitoring.

TVA will send one engineer to BHEL in Trichy to participate in the onsite emissions monitoring.

BHEL engineers will visit TVA sites during the spring of 1992 to observe the monitoring of $\mathrm{NO}_{x}$ and $\mathrm{SO}_{2}$ and for discussions with TVA on control technologies for $\mathrm{NO}_{x}$ and $\mathrm{SO}_{2}$.

4.0 Deliverables:

1. A report by TVA on the results of the Emissions Monitoring and Boiler Life Assesment conducted in India.

2. Information/recormendations specific to environmental controls and life extension of the boilers.

3. A technical paper by TVA and BHEL presented at a joint workshop in India or the United States.

\subsection{Discussion of Results:}

The emissions monitoring was performed on VTPS's unit 1 , a 210-MW, tangentially-fired, pulverized coal boiler. The traveler, along with Mr. K. Chandrasekaran, BHEL, and Mr. Nagaraja Rao, CPRI, performed the monitoring. TVA, BHEL, and CPRI provided the test equipment. The gaseous sample was extracted from the duct at the electrostatic precipitator (ESP) outlet up stream of the induced draft fans. It was routed through a sample conditioning system and then to each analyzer. The gas sample was analyzed for $\mathrm{NO}_{x}, \mathrm{SO}_{2}, \mathrm{CO}$, and $\mathrm{O}_{2}$. Coal samples from the feeders, bot tom ash samples, and ash samples from the ESP hoppers were taken during each test. Coal fineness testing was 
performed one time during the test program.A total of 12 tests were performed during the four day period. Six tests were run with the air dampers associated with the F-mill, which are identified as (F\&FF) by BHEL, closed while varying the excess air and the fuel-air damper (FAD) position. Another 6 tests were run with the F\&FF dampers open, simulating over-fire air OFA conditions while varying the excess ir and the FAD position. There were two positions for the FADs, the normal position of 20 percent open and the test condition of 5 percent open. The excess air was varied from 15 to 25 percent.

\subsection{Data:}

The data presented in this report should not be accepted as absolute values for emissions from Indian coal plants. However, the data does follow expected trends for reduction in $\mathrm{NO}_{\mathbf{x}}$ emissions when simulating an OFA condition and for characterizing the $\mathrm{NO}_{x}$ sensitivity to excess air and load reductions. The accuracy of the values reported is questionable due to the lack of adequate calibration before and during the testing. Apparently procuring large amounts of calibration gas in India is a problem, not only due to the lack of suppliers, but also to the quality or accuracy of the concentrations of the gases. If India is going to initiate an emissions monitoring program, they must first address this problem to insure the accuracy of the data generated. This is a severe problem since it could render the data generated meaningless.

Several other problems associated with the analyzers transported to India by TVA and PETC contributed to the matter of questionable accuracy. The Beckman $\mathrm{SO}_{2}$ analyzer failed, the Fuji CO analyzer worked properly, but there was not enough calibration gas to adequately calibrate it. The portable Land Combustion analyzer, carried as a back-up failed also. The other analyzers performed well, but could not be calibrated of ten enough while others were not EPA-approved because they are electrochemical cell-type portables. This does not mean that they are not accurate, but only that they are not EPA-approved methods. If additional testing is performed in India, approved analyzers must be made available in India. 
The data in this report was taken utilizing the following instrumentation:

$\begin{array}{lcc}\text { Analyzer } & \text { Constituent } & \text { Owner } \\ \text { Shimadzu } & & \\ \text { Teledyne } & \mathrm{NO}_{x} & \text { CPRI } \\ \text { LandCom } & \mathrm{O}_{2} & \text { TVA } \\ \text { LandCom } & \mathrm{CO}^{-} & \text {BHEL } \\ \text { SCS } & \mathrm{SO}_{2} & \text { BHEL } \\ \text { Probe } & & \text { TVA } \\ & & \text { TVA }\end{array}$

\subsection{Results:}

At typical unit operating conditions, 200 MW and 20 percent excess air, the $\mathrm{NO}_{x}$ averaged $309 \mathrm{ppm}$ corrected to 3 percent $\mathrm{O}_{2}$ or $0.42 \mathrm{lbs} / \mathrm{MBtu}$. The $\mathrm{SO}_{2}$ averaged $395 \mathrm{ppm}$ actual conditions) or 0.96 lbs/MBtu (Table 2). When the OFA simulation test was performed (test 07), the $\mathrm{NO}_{x}$ averaged $185 \mathrm{ppm}$ corrected to 3 percent $\mathrm{O}_{2}$ or 0.25 Ibs/ABtu. The magnitude of the reduction of $\mathrm{NO}_{x}$ during the OFA simulation was greater than expected. Typically, OFA will result in only approximately 20-25 percent reduction. In this case, it was about 40 percent, which is not in line with data taken at TVA plants. As stated above the data may not reflect the actual values for emissions.

In all cases, closing the FADs to 5 percent open resulted in a decrease in $\mathrm{NO}_{x}$ emissions. The graphics (Figures 1-3) show the effect of changing the FAD from the normal position of 20 percent open, to the 5 percent open positions when the F\&FF dampers are closed. Typically, when evaluating control techniques expected to affect $\mathrm{NO}_{x}$ formation, the FADs are left in the 100 percent open position. However, BHEL preferred to change the settings for this evaluation. This configuration needs to be evaluated with respect to unit operating conditions such as flame stability, flame length, and combustibles in the ash before drawing any conclusions. There is a possibility that this configuration has a quenching effect on the flame, thereby lowering the temperature and decreasing the thermal $\mathrm{NO}_{x}$ formation, or it may delay the devolatilization of the coal during the combustion process. Additional testing would be required to evaluate the effects of this mode of operation. 
Figures 4-6 show the effect of adjusting the FAD to 5 percent open when simulating OFA. Figures 7-12 compare the effect of excess air on $\mathrm{NO}_{x}$ emissions with and without simulated OFA, and at both FAD settings.

In all but one case, increasing excess air increased $\mathrm{NO}_{\mathbf{x}}$ emissions, as would be expected, while decreasing excess air decreased $\mathrm{NO}_{x}$ emissions.

A summary of the actual test conditions is included to help clarify the data, i.e., on occasion, the actual excess air was less than or greater than the target and this must be considered when evaluating the results. Actual test conditions were as follows:

ACTUAL TEST CONDITIONS

\begin{tabular}{|c|c|c|c|c|c|c|}
\hline TEST & $\begin{array}{l}\text { LOAD } \\
\text { MW }\end{array}$ & $\begin{array}{l}\text { BOILER } \\
02(\%)\end{array}$ & $\begin{array}{l}\text { TARGET } \\
\text { EX AIR } \\
(z) \\
\end{array}$ & $\begin{array}{l}\text { ACTUAL } \\
\text { EX AIR } \\
(z)\end{array}$ & $\begin{array}{l}\text { FAD } \\
\mathbf{Z} \text { OPEN } \\
\end{array}$ & $\begin{array}{l}\text { NOx } \\
\text { LBS. }\end{array}$ \\
\hline $\begin{array}{l}01 \\
02 \\
03 \\
04 \\
05 \\
06 \\
07 \\
08 \\
09 \\
10\end{array}$ & $\begin{array}{l}200 \\
210 \\
211 \\
182 \\
181 \\
182 \\
210 \\
206 \\
187 \\
185 \\
181 \\
185\end{array}$ & $\begin{array}{l}3.6 / 3 / 2 \\
3.8 / 3.8 \\
4.4 / 4.3 \\
3.8 / 4.0 \\
2.6 / 3.2 \\
3.0 / 3.2 \\
4.0 / 3.9 \\
3.5 / 3.0 \\
4.0 / 4.5 \\
4.5 / 4.7 \\
2.4 / 3.5 \\
3.0 / 3.5\end{array}$ & $\begin{array}{l}20 \\
20 \\
25 \\
25 \\
15 \\
15 \\
20 \\
20 \\
25 \\
25 \\
15 \\
15\end{array}$ & $\begin{array}{l}19 \\
22 \\
26 \\
23 \\
16 \\
17 \\
24 \\
18 \\
26 \\
28 \\
16 \\
22\end{array}$ & $\begin{array}{l}20 \\
05 \\
20 \\
05 \\
20 \\
05 \\
20 \\
05 \\
20 \\
05 \\
20 \\
05\end{array}$ & $\begin{array}{l}0.42 \\
0.35 \\
0.41 \\
0.32 \\
0.34 \\
0.25 \\
0.25 \\
0.23 \\
0.36 \\
0.30 \\
0.29 \\
0.28\end{array}$ \\
\hline
\end{tabular}

The $\mathrm{NO}_{x}$ emissions expressed as $1 \mathrm{bs} / \mathrm{MBtu}$ were calculated according to EPA requirements using an E factor of 9780. An $F$ factor is the ratio of the gas volume of the products of combustion to the heat content of the fuel. When the analyses from the Indian coal are received, the emission rates may be adjusted.

No attempt was made to characterize $\mathrm{NO}_{x}$ reduction versus boiler load since changing the damper settings and percent excess air during the testing complicates the analysis. However, the data indicate that $\mathrm{NO}_{x}$ emissions decrease as the boiler load decreases. 
The $\mathrm{SO}_{2}$ emissions ranged from $0.92 \mathrm{lbs} / \mathrm{MBtu}$ to 1.37

Ibs/MBtu. However, since all of this data was taken with the cell-type analyzer, additional testing should be performed using ultraviolet absorption methods before drawing any conclusions.

The carbon monoxide ( $\mathrm{CO}$ ) emissions followed the expected trend, i.e., increasing excess air, decreases $c 0$ emissions. The CO emissions were somewhat higher than the typical emissions from TVA units.

To determine actual baseline gaseous emissions at the Indian plants and have confidence in the resuiting data, the testing should be performed using approved techniques and analyzers for all flue gas constituents. Although it was the intent of this program to do just that, problems with the transported equipment prevented approved $\mathrm{SO}_{2}$ and $\mathrm{CO}$ measurements. The following list is an example of equipment meeting EPA requirements. This list is only meant to be an example of the approved principles of operation and is not an endorsement by TVA for any vendor or product.

ANALYZERS

6.0 Analyzers:

Oxygen

02 analyzer; Beckman Instruments Model 755 Paramagnetic analyzer. Analysis is based on the measurement of the magnetic susceptibility of the sampled gas. Oxygen is strongly paramagnetic. Other common gases, with only a few exceptions, are weakly diamagnetic.

The nominal operating range is $0-25$ percent. The analyzer has an accuracy of $+/-1$ percent.

\section{Carbon Monoxide}

CO analyzer; Beckman Instruments Model 880 Non-Dispersive Infrared analyzer. Analysis is based on the measurement of absorbed infrared energy.

The nominal operating range is $0-200 \mathrm{ppm}$. The analyzer has an accuracy of $+/-1$ percent. 


\section{Carbon Dioxide}

CO2 analyzer; Beckman Instruments Model 880 Non-Dispersive Infrared analyzer. Analysis is based on the measurement of absorbed infrared energy.

The nominal operating range is $0-20$ percent. The analyzer has an accuracy of $+/-1$ percent.

\section{Nitrogen Oxides}

NO/NO analyzer; Thermo-Electron Model 10AR. Analysis is based on the chemiluminescent principle. To measure NO concentrations, the gas sample to be analyzed is blended with ozone in a reaction chamber. The resulting cherailuminescence is monitored through an optical filter by a high-sensitivity photomultiplier positioned at one end of the chamber. The filter/photomultiplier combination responds to light in a narrow-wavelength band unique to the above reaction. The output from the photomultiplier is linearly proportional to the NO concentration.

To measure $\mathrm{NO}_{x}$ concentrations (i.e., NO plus $\mathrm{NO}_{2}$ ), the sample gas flow is diverted through an $\mathrm{NO}_{2}$-to-NO converter. The chemiluminescent response in the reaction chamber to the converter effluent is linearly proportional to the $\mathrm{NO}_{x}$ concentration entering the converter.

The nominal operating range is $0-1000 \mathrm{ppm}$. The accuracy is $+/-1$ percent of full scale.

\section{Sulfur Dioxide}

$\mathrm{SO}_{2}$ analyzer; Western Research Model 721AT, Ultraviolet absorption. The analyzer design is based upon a single source emitting the appropriate wavelengths. The radiation from the source is chopped by a single pair of narrow-band pass radiation rejection filters rotated through the path and then split into two paths, measurement and reference. The measuring path contains the cell through which the flue gas sample is passed; the reference path contains the sealed sample cell which is filled with instrument-quality air.

The radiation passed by the cells is then detected by a pair of photomultiplier tubes (PMT), one for each radiation path. It is these signals which are used in the calculation of the final output.

The nominal operating range is $0-5000 \mathrm{ppm}$. The accuracy of the analyzer is $+/-2$ percent of full scale. 


\subsection{Conclusions:}

NO $_{x}$ enissions from VTPS unit 1, appear to be less than the maximum allowable limit, as set forth by the "Clean Air Act Amendment" (CAAA), for the United States. And there is a substantial reduction in NOx emissions when operating in the -imulated OFA condition. The data also show that closing the fuel-air dampers to the 5 percent position decreases $\mathrm{NO}_{x}$ emissions. This mode of operation warrents further investigation.

The $\mathrm{SO}_{2}$ emissions appear to be borderline for meeting the CAAA limits of 1.2 lbs/MBtu. CO emissions are higher than typical emissions for the TVA tangential-fired units.

Overall, the test program was very successful. It was a learning process for all parties involved, and any future exchange programs will benefit from the lessons learned during this program.

TEST SUMALARY

\begin{tabular}{|c|c|c|c|c|c|c|c|}
\hline $\begin{array}{l}\text { TEST } \\
\text { NO }\end{array}$ & $\begin{array}{c}\text { F\&FF } \\
\text { DAMPER }\end{array}$ & $\begin{array}{r}X S \\
\text { AIR } \\
\end{array}$ & $\begin{array}{c}\text { FAD } \\
\text { DAMPER }\end{array}$ & $\begin{array}{l}\text { LOAD } \\
\text { NW }\end{array}$ & $\begin{array}{l}\text { CO } \\
\text { PPM }\end{array}$ & $\begin{array}{c}\text { NOx } \\
\text { LBS } A \text { ABt }\end{array}$ & $\begin{array}{c}\mathrm{SO}_{2} \\
\text { LBS MBLU }\end{array}$ \\
\hline $\begin{array}{l}01 \\
02 \\
03 \\
04 \\
05 \\
06 \\
07 \\
08 \\
09 \\
10 \\
11 \\
12\end{array}$ & $\begin{array}{l}\text { CLOSED } \\
\text { CLOSED } \\
\text { CLOSED } \\
\text { CLOSED } \\
\text { CLOSED } \\
\text { CLOSED } \\
\text { OPEN } \\
\text { OPEN } \\
\text { OPEN } \\
\text { OPEN } \\
\text { OPEN } \\
\text { OPEN }\end{array}$ & $\begin{array}{l}20 \% \\
20 \% \\
25 \% \\
25 \% \\
15 \% \\
15 \% \\
20 \% \\
20 \% \\
25 \% \\
25 \% \\
15 \% \\
15 \%\end{array}$ & $\begin{array}{c}\text { NORYAL } \\
5 \% \\
\text { NORYAL } \\
5 \% \\
\text { NORYAL } \\
5 \% \\
\text { NORYAL } \\
5 \% \\
\text { NORYAL } \\
5 \% \\
\text { NORYAL } \\
5 \%\end{array}$ & $\begin{array}{l}200 \\
210 \\
211 \\
182 \\
181 \\
183 \\
211 \\
206 \\
187 \\
185 \\
181 \\
185\end{array}$ & $\begin{array}{r}100 \\
70 \\
93 \\
121 \\
135 \\
79 \\
95 \\
108 \\
72 \\
72 \\
63 \\
40\end{array}$ & $\begin{array}{l}0.42 \\
0.35 \\
0.41 \\
0.32 \\
0.34 \\
0.25 \\
0.25 \\
0.23 \\
0.36 \\
0.30 \\
0.29 \\
0.28\end{array}$ & $\begin{array}{l}0.96 \\
1.37 \\
1.30 \\
1.30 \\
1.18 \\
1.21 \\
1.10 \\
1.08 \\
* \\
0.92 \\
0.95 \\
0.94\end{array}$ \\
\hline
\end{tabular}


$\vdots$
$\vdots$
$i$
$i$
1

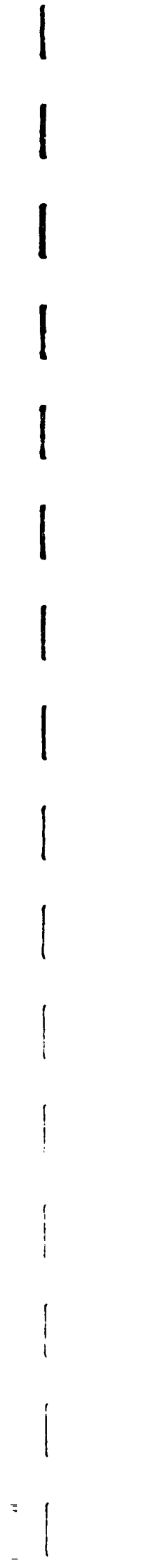


EMISSIONS MUNITORING FOR NOX SO2

VIJAYAWADA TPS (FEBRUARY 1992)

PARAMETERS TO BE KEPT CONSTANT FOR ALC THE TESTS:

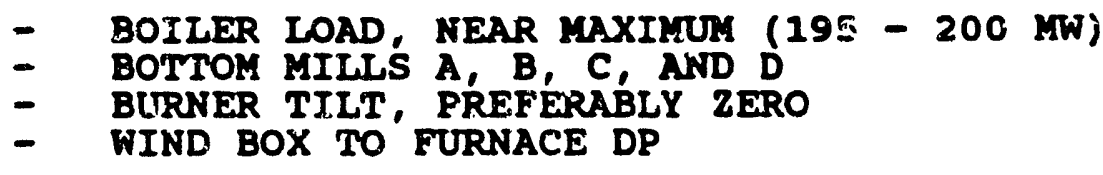

TEST MATRIX:

\begin{tabular}{cccc}
$\begin{array}{c}\text { TEST } \\
\text { NO }\end{array}$ & $\begin{array}{c}\text { F F FF } \\
\text { DAMPERS }\end{array}$ & $\begin{array}{c}\text { EXCESS } \\
\text { AIR }\end{array}$ & $\begin{array}{c}\text { FAD } \\
\text { OPEN }\end{array}$ \\
\hline 1 & CLOSED & $20 \%$ & $20 \%$ (NORMAL) \\
2 & CLOSED & $20 \%$ & $5 \%$ \\
3 & CLOSED & $25 \%$ & $20 \%$ \\
4 & CLOSED & $25 \%$ & $5 \%$ \\
5 & CLOSED & $15 \%$ & $20 \%$ \\
6 & CLOSED & $15 \%$ & $5 \%$ \\
7 & OPEN & $20 \%$ & $20 \%$ \\
8 & OPEN & $20 \%$ & $5 \%$ \\
9 & OPEN & $25 \%$ & $20 \%$ \\
10 & OPEN & $25 \%$ & $5 \%$ \\
11 & OPEN & $15 \%$ & $20 \%$ \\
12 & OPEN & $15 \%$ & $5 \%$
\end{tabular}

- 3 CONTROI ROOM READINGS FOR EACH TEST; FIRST SET OF READINGS AFTER CNE HOUR OF STABILIZED BOILER OPERATION; SUBSEQUENT READINGS AT 15 MINUTE INTERVALS

- ANALYZER peADINGS FROM NOX, SO2, CO, LANCOM 3400 AND TELEDXNE, 5 MENUTE INTERVALS

- BOILER BOARD READINGS AS LISTEN IN THE TABULATION

- RAW COAL SAMPLES FROM INLET TO ALL FOUR OPERATIAG FEEDERS, 5 TO 10 MINUTES PRIOR TO EACH READING ('LUTAL OF 12 SAMPLES PER TEST)

- ONE BOTTOM ASH SAMPLE PER TEST

- FLY ASH SAMPIES FROM UNE RON OF ESP HOPPERS, ONE/TEST

- ONE COAL FINENESS TEST PER DAY ON ALL OPERATING MILLS 
VIJAYAMDA PLANT TEST DATA

zOOM. TYPICAL OPERATIONS, NONMAL FAD, F FF DAMPER CLOSED

TEST 1

DATE: $2 \pi / 92$

\begin{tabular}{|c|c|c|c|c|c|c|c|c|c|}
\hline IIIEe & $\begin{array}{l}\text { (1) } \\
\text { Low } \\
1\end{array}$ & $\begin{array}{c}\text { (2) } \\
\text { DOILER } \\
\text { OER }\end{array}$ & $\begin{array}{c}\text { (3) } \\
\operatorname{sez} \\
\cdots=d r y\end{array}$ & $\begin{array}{l}(6) \\
02 \\
x, d y\end{array}$ & $\begin{array}{l}\text { (5) } \\
\infty \\
\text { pin,dry }\end{array}$ & $\begin{array}{c}\text { (6) } \\
\text { wox } \\
\text { pindory }\end{array}$ & $\begin{array}{c}\text { (7) } \\
\text { wox pom } \\
03 \% \text { o2 }\end{array}$ & $\begin{array}{c}\text { (8) } \\
\text { nox } \\
\text { tb/abtu }\end{array}$ & $\begin{array}{c}(9) \\
802 \\
\text { Ib/atu }\end{array}$ \\
\hline $14: 20$ & 200 & 3.6 & 390 & 6.80 & 108.0 & 261 & 305 & 0.42 & 0.96 \\
\hline $16: 25$ & 200 & 3.6 & 397 & 6.80 & 106.0 & 247 & 313 & 0.43 & 0.96 \\
\hline $16: 30$ & 200 & 3.4 & $3 \%$ & 6.80 & 105.0 & 256 & 322 & 0.46 & 0.96 \\
\hline $14: 35$ & 200 & 3.4 & 384 & 6.90 & 101.0 & 250 & 319 & 0.46 & 0.93 \\
\hline $16: 40$ & 200 & 3.6 & 303 & 7.00 & 100.0 & 250 & 321 & 0.66 & 0.26 \\
\hline $14: 65$ & 200 & 3.4 & 394 & 6.80 & 97.0 & 268 & 314 & 0.63 & 0.95 \\
\hline $14: 50$ & 200 & 3.6 & 385 & 6.80 & 98.0 & 248 & $31:$ & 0.63 & 0.93 \\
\hline $14: 55$ & 200 & 3.4 & 383 & 6.90 & 98.0 & 250 & 319 & 0.66 & 0.93 \\
\hline $15: 00$ & 200 & 3.4 & 388 & 6.90 & 98.0 & 250 & 319 & 0.64 & 0.94 \\
\hline $15: 05$ & 200 & 3.6 & 388 & 6.80 & 96.0 & 260 & 304 & 0.42 & 0.94 \\
\hline $15: 10$ & 200 & 3.4 & 386 & 6.80 & 97.0 & 241 & 305 & 0.42 & 0.93 \\
\hline $15: 15$ & 200 & 3.4 & 398 & 6.80 & 95.0 & 235 & 298 & 0.41 & 0.96 \\
\hline $15: 20$ & 200 & 3.6 & 605 & 6.60 & 98.0 & 229 & 286 & 0.39 & 0.96 \\
\hline $15: 25$ & 200 & 3.4 & 611 & 6.70 & $\boldsymbol{9 0 . 0}$ & 260 & 302 & 0.61 & 0.99 \\
\hline $15: 30$ & 200 & 3.6 & 431 & 6.80 & 100.0 & 235 & 298 & 0.41 & 1.06 \\
\hline AVos: & 200 & 3.6 & 395 & 6.81 & 99.5 & 246 & 309 & 0.42 & 0.96 \\
\hline
\end{tabular}

(1) Unit laad recordad from control baard.

(2) averees boller 02, recorded from control boerd.

(3) messurement of duct s02, dry basis, BHEL, LNO-CON.

(4) Messurement of duct 02, dry basis, TVA, TELEDYME.

(5) measurement of $\infty$, Ppon, dry basis, BHEL, LNND-CON.

(6) Measurement of mox, ppa, dry besis, CPRI, SHIMMDZW.

(7) nox pow corrected to $3 \times 02$

(8) Enission rate, wox, Ib/wTU, calculated from duct wox mesurements.

(9) Enission rate, s02, lb/maru, calculated fren duct so2 esecurements. 
VIJAYAMNA PLANT TEST DATA

210 MW, $20 X$ EXCESS AIK, FAD 5X OPEN, F \& FF CLOSEO

TEST 2

DATE: 2/7/92

\begin{tabular}{|c|c|c|c|c|c|c|c|c|c|}
\hline TIME & $\begin{array}{l}\text { (1) } \\
\text { Lond } \\
\mathrm{in}\end{array}$ & $\begin{array}{c}\text { (2) } \\
\text { OOILER } \\
\text { OEs }\end{array}$ & $\begin{array}{c}\text { (3) } \\
502 \\
\text { Prem,dry }\end{array}$ & $\begin{array}{l}(4) \\
02 \\
x, d r y\end{array}$ & $\begin{array}{l}\text { (5) } \\
\infty \\
p \text { p.dmy }\end{array}$ & $\begin{array}{l}\text { (6) } \\
\text { nox } \\
\text { pem,dry }\end{array}$ & $\begin{array}{c}(7) \\
\operatorname{mox} p \\
13 x \text { or }\end{array}$ & $\begin{array}{c}\text { (8) } \\
\text { 10x } \\
\text { Ib/chtu }\end{array}$ & $\begin{array}{c}\text { (9) } \\
802 \\
\text { Ib/motu }\end{array}$ \\
\hline $17: 08$ & 210 & 3.8 & 550 & 7.20 & 81.0 & 206 & 269 & 0.37 & 1.37 \\
\hline $17: 15$ & 210 & 3.8 & 551 & 7.20 & 73.0 & 197 & 257 & 0.35 & 1.37 \\
\hline $17: 20$ & 210 & 3.8 & 551 & 7.10 & 70.0 & 195 & 253 & 0.35 & 1.36 \\
\hline $17: 25$ & 210 & 3.8 & 559 & 7.10 & 68.0 & 199 & 258 & 0.35 & 9.36 \\
\hline $17: 30$ & 210 & 3.8 & 560 & 7.00 & 66.0 & 199 & 256 & 0.35 & 1.37 \\
\hline $17: 35$ & 210 & 3.8 & 563 & 7.00 & 65.0 & 193 & 248 & 0.34 & 1.38 \\
\hline $17: 40$ & 210 & 3.8 & 565 & 7.00 & 65.0 & 195 & 251 & 0.34 & 1.38 \\
\hline $17: 45$ & 210 & 3.8 & 554 & 7.40 & 70.0 & 208 & 275 & 0.38 & 1.60 \\
\hline AVGS: & 210 & 3.8 & 556 & 7.13 & 69.8 & 199 & 258 & 0.35 & 1.37 \\
\hline
\end{tabular}

(1) Unit laed recorded fram control bourd.

(2) Average boller 02, recordad from control board.

(3) measurement of duct 502 , dry besis, BHEL, LANO-con.

(4) Measurement of duct 02, dry basis, TVA, TELEDYME.

(5) Measurement of $\infty$, Ppm, dry basis, BHEL, LAMD-CON.

(6) Measurcement of 10X, ppom, ory besis, CPRI, SHIMNDZU.

(7) $10 x$ pon corrected to $3 x$ oz.

(8) Enission rate, nox, Ib/matu, calculated from duct wox measurements.

(9) Eniseion rate, so2, Ib/maru, calculated from duct so2 masuraments. 
VI JAYAMEA PLANT TEST DATA

291 m, 25\% EXCESS AIR, TYPICAL FAD, F FF DAMPERS CLOSED

TEST 3

DATE: $2 / 7 / 92$

\begin{tabular}{|c|c|c|c|c|c|c|c|c|c|}
\hline TIME & $\begin{array}{l}\text { (1) } \\
\text { Lond } \\
\text { Mu }\end{array}$ & $\begin{array}{c}\text { (2) } \\
\text { DOILER } \\
\text { OLX }\end{array}$ & $\begin{array}{c}\text { (3) } \\
802 \\
\text { Ppon,dry }\end{array}$ & $\begin{array}{l}(6) \\
02 \\
x, d r y\end{array}$ & $\begin{array}{c}(5) \\
\infty \\
0 m, d m y\end{array}$ & $\begin{array}{c}\text { (6) } \\
\text { uxx } \\
p \text { p.diny }\end{array}$ & $\begin{array}{l}\text { (7) } \\
\operatorname{mox} P \operatorname{pm} \\
\operatorname{cx} 02\end{array}$ & $\begin{array}{c}\text { (8) } \\
\text { nox } \\
\text { lb/mbtu }\end{array}$ & $\begin{array}{c}(9) \\
502 \\
\text { lb/mbtu }\end{array}$ \\
\hline $21: 08$ & 211 & 4.6 & 511 & 7.40 & 93.0 & 227 & 300 & 0.27 & 1.20 \\
\hline $21: 12$ & 211 & 4.4 & 519 & 7.40 & 90.0 & 226 & 299 & 0.26 & 1.31 \\
\hline $21: 15$ & 211 & 4.6 & 510 & 7.50 & 88.0 & 227 & 303 & 0.61 & 1.30 \\
\hline $21: 20$ & 211 & 4.4 & 508 & 7.60 & 86.0 & 225 & 302 & 0.41 & 1.30 \\
\hline $21: 25$ & 211 & 4.4 & 505 & 7.50 & 84.0 & 221 & 295 & 0.40 & 1.28 \\
\hline $21: 30$ & 211 & 4.6 & 505 & 7.40 & 83.0 & 221 & 293 & 0.61 & 1.27 \\
\hline $21: 35$ & 211 & 4.4 & 511 & 7.50 & 83.0 & 223 & 297 & 0.41 & 1.30 \\
\hline $21: 40$ & 211 & 4.4 & 505 & 7.50 & 82.0 & 219 & 292 & 0.40 & 1.28 \\
\hline $21: 45$ & 211 & 4.4 & 491 & 7.90 & 9.0 & 265 & 337 & 0.45 & 1.29 \\
\hline $21: 50$ & 219 & 4.4 & 516 & 7.60 & 112.0 & $\bullet$ & 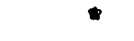 & 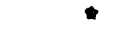 & 1.32 \\
\hline $21: 55$ & 211 & 4.4 & 515 & 7.50 & 107.0 & • & $\star$ & - & 1.31 \\
\hline $22: 00$ & 211 & 4.4 & 510 & 7.50 & 110.0 & $\bullet$ & $\bullet$ & - & 1.30 \\
\hline $22: 05$ & 211 & 4.4 & 511 & 7.40 & 100.0 & 234 & 310 & 0.43 & 1.29 \\
\hline $22: 18$ & 211 & 4.4 & 591 & 7.40 & 93.0 & 227 & 300 & 0.62 & 1.29 \\
\hline AVGS: & 211 & 4.4 & 509 & 7.51 & 93.2 & 227 & 303 & 0.41 & 1.30 \\
\hline
\end{tabular}

(1) Unit loed recorded fram control boord.

(2) Averege boller 02, recorded from control board.

(3) Measurement of duct 502, dry basis, BHEL, LAND-con.

(4) Measurement of duct 02, dry besis, TYA, TELEDYME.

(5) Measurement of $\mathrm{CD}$, Ppa, dry basis, BMEL, LAND-CON.

(6) Measurement of wOx, ppm, dry basis, CPRI, SHIMnOzU.

(7) Mox pan corrected to $3 \% 02$.

(8) Enission rate, wox, Ib/esT, colculated from duct wox mosurements.

(9) Enission rate, $502,1 b / m 3 T$, colculoted from duct 502 moveurements.

(*) NO DATA RECORDED 
VI JAYAHAN PLANT TEST DATA

182 MN, 25\% EXCESS AIR, FAD 5\% OPEN, F \& FF DAMPERS ClOSED

TEST 4

DATE: $2 / 9 / 92$

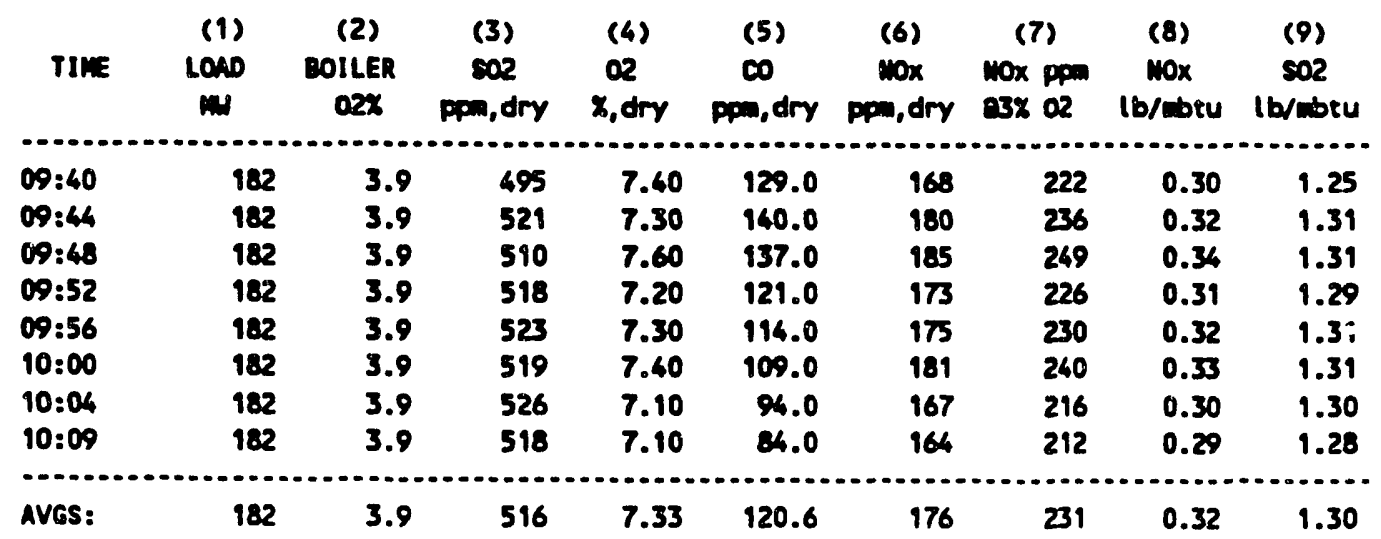

(1) Unit land recorded from control board.

(2) Average boiler 02, recorded fron control boerd.

(3) Measurewent of duct s02, dry basis, BHEL, LNM-con.

(4) Messurement of duct 02, dry besis, TVA, TELEDYME.

(5) Measureanent of CO, Ppm, dry besis, BWEL, LAD-con.

(6) Measurcuent of wOx, ppm, dry basis, CPRI, SHIMLOZW.

(7) wox ppon corrected to $3 x 02$.

(8) Enfseion rate, Max, Ib/sisu, celculoted fron duct wox mesurements.

(9) Eaission rate, 502 , lb/mBTU, calculated from duct 802 masuraments. 


\section{JAYAMADA PLANT TEST DATA}

181 MA, 15: EXCESS AIR, TYPICAL FAD, F IF DAMERS CLOSED

TEST 5

DATE: $2 / 9 / 92$

\begin{tabular}{|c|c|c|c|c|c|c|c|c|c|}
\hline TIME & $\begin{array}{l}\text { (1) } \\
\text { Lond } \\
\text { mid }\end{array}$ & $\begin{array}{c}\text { (2) } \\
\text { COILER } \\
\text { O2X }\end{array}$ & $\begin{array}{c}\text { (3) } \\
8 \infty 2 \\
\text { Ppinddry }\end{array}$ & $\begin{array}{l}(4) \\
02 \\
x, d m y\end{array}$ & $\begin{array}{c}\text { (5) } \\
\infty \\
p \text { odry }\end{array}$ & $\begin{array}{l}\text { (6) } \\
\text { mox } \\
\text { Ppen,dry }\end{array}$ & $\begin{array}{c}(7) \\
\operatorname{mox} \text { ppm } \\
\text { e3x o2 }\end{array}$ & $\begin{array}{c}\text { (8) } \\
10 x \\
\text { lb/mbtu }\end{array}$ & $\begin{array}{c}(9) \\
802 \\
\text { (b/abtu }\end{array}$ \\
\hline $12: 20$ & 181 & 2.9 & 505 & 6.30 & 282.0 & 174 & 213 & 0.29 & 1.18 \\
\hline $12: 26$ & 181 & 2.9 & 506 & 6.30 & 287.0 & 977 & 217 & 0.30 & 1.18 \\
\hline $12: 28$ & 181 & 2.9 & 674 & 7.30 & 91.0 & 218 & 226 & 0.39 & 1.19 \\
\hline $12: 36$ & 181 & 2.9 & 490 & 6.80 & $\pi .0$ & 201 & 255 & 0.35 & 1.18 \\
\hline $12: 40$ & 181 & 2.9 & 484 & 6.90 & 70.0 & 206 & 263 & 0.36 & 1.18 \\
\hline $12: 44$ & 181 & 2.9 & 490 & 6.80 & 66.0 & 204 & 259 & 0.35 & 1.18 \\
\hline $12: 48$ & 181 & 2.9 & 491 & 6.80 & 69.0 & 195 & 247 & 0.34 & 1.19 \\
\hline AVGS: & 181 & 2.9 & 491 & 6.74 & 134.6 & 196 & 248 & 0.34 & 1.18 \\
\hline
\end{tabular}

(1) Unit loed recorded from control bourd.

(2) Average boiler 02, recordad from control board.

(3) Measurement of duct 502 , dry besis, BHEL, LNDO-COM.

(6) Mesurement of duct 02 , dry basis, TVA, TELEDYME.

(5) Measurcient of Co, pom, drY basis, BHEL, LAND-CON.

(6) Meesurament of NOX, Ppon, dry besis, CPRI, SHIMNZU.

(7) wox ppon corrected 3x 02.

(8) Enission rate, MOx, Ib/msTu, calculated fran duct mox mesurements.

(9) Enission rate, s02, Ib/waTu, calculoted from duct so2 measurements. 
viJAYAMANA PLANT TEST DATA

183 MW, 15X EXCESS AIR, FAD 5X OPEN, F 2 FF DAMPERS CLOSED

TEST 6

DATE: $2 / 9 / 92$

\begin{tabular}{|c|c|c|c|c|c|c|c|c|c|}
\hline TINE & $\begin{array}{c}(9) \\
\operatorname{Lon} 0 \\
M\end{array}$ & $\begin{array}{l}\text { (2) } \\
\text { BOILER } \\
\text { O2X }\end{array}$ & $\begin{array}{l}\text { (3) } \\
s 02 \\
p p m, d r y\end{array}$ & $\begin{array}{l}(4) \\
02 \\
x, d r y\end{array}$ & $\begin{array}{c}\text { (5) } \\
\infty \\
p p=, d r y\end{array}$ & $\underbrace{(6)}_{p p o x, d r y}$ & $\begin{array}{c}\text { (7) } \\
\text { 10x ppm } \\
03 \times 02\end{array}$ & $\begin{array}{c}\text { (8) } \\
\text { nox } \\
\text { 1b/abtu }\end{array}$ & $\begin{array}{c}(9) \\
502 \\
\text { Ib/ubtu }\end{array}$ \\
\hline $10: 45$ & 183 & 3.1 & 492 & 7.10 & 93.0 & 159 & 206 & 0.28 & 1.21 \\
\hline $10: 53$ & 183 & 3.1 & 474 & 7.40 & 79.0 & 159 & 210 & 0.29 & 1.20 \\
\hline $10: 57$ & 183 & 3.1 & 506 & 6.70 & 76.0 & 137 & 172 & 0.24 & 1.21 \\
\hline $11: 01$ & 183 & 3.1 & 504 & 6.70 & 61.0 & 135 & 170 & 0.23 & 1.21 \\
\hline $11: 05$ & 183 & 3.1 & 507 & 6.60 & 62.0 & 135 & 169 & 0.23 & 1.21 \\
\hline $11: 09$ & 183 & 3.1 & 482 & 7.10 & 48.0 & 147 & 190 & 0.26 & 1.19 \\
\hline $19: 13$ & 183 & 3.1 & 490 & 6.80 & 48.0 & 150 & 190 & 0.26 & 1.18 \\
\hline IVGS: & 183 & 3.1 & 497 & 6.86 & 78.6 & 145 & 184 & 0.25 & 1.21 \\
\hline
\end{tabular}

(1) Unit laed recorded from control board.

(2) Average boiler 02, recorded from control boord.

(3) weseureasent of duct s02, dry besis, BHEL, LAND-con.

(4) Meseurament of duct 02, dry basis, TVA, TELEDYME.

(5) Meseurement of CO, PpD, dry besis, BHEL, LANO-CON.

(6) Mesaurement of MOx, Ppon, dry basis, CPRI, SHIMUDZU.

(7) wox ppo corrected to $3 \times 02$.

(8) Enission rate, MOx, Ib/wBTU, calculated from duct NOx mesurements.

(9) Enission rate, 502 , Ib/mbTU, calculated from duct 502 measurcments. 


\section{JAYALADA PLAMT TEST DATA}

$211 \mathrm{~m}, 20 \%$ EXCESS AIR, OFA SIMULATION, F 2 FF DAMPERS OPEN

DATE: $2 / 8 / 92$

\begin{tabular}{|c|c|c|c|c|c|c|c|c|c|}
\hline TIME & $\begin{array}{c}\text { (1) } \\
\text { LOND } \\
\text { nin }\end{array}$ & $\begin{array}{l}\text { (2) } \\
\text { DOILER } \\
\text { O2X }\end{array}$ & $\begin{array}{c}\text { (3) } \\
802 \\
\text { Pin, dry }\end{array}$ & $\begin{array}{l}(4) \\
02 \\
x, d r y\end{array}$ & $\begin{array}{l}\text { (5) } \\
\infty \\
P \text { d dry }\end{array}$ & $\begin{array}{l}\text { (6) } \\
\operatorname{mox} \\
\text { Pan,dry }\end{array}$ & $\begin{array}{c}\text { (7) } \\
\text { wox pion } \\
\text { ebs o2 }\end{array}$ & $\begin{array}{c}\text { (8) } \\
m 0 x \\
\text { lb/cotu }\end{array}$ & $\begin{array}{c}\text { (9) } \\
\mathrm{so2} \\
\text { lo/cotu }\end{array}$ \\
\hline $0: 50$ & 211 & 4.0 & 452 & 6.80 & 116.0 & 151 & 193 & 0.26 & 1.09 \\
\hline $0: 55$ & 211 & 4.0 & 456 & 6.80 & 112.0 & 142 & 181 & 0.25 & 1.10 \\
\hline $11: 00$ & 291 & 4.0 & 456 & 6.80 & 105.0 & 143 & 183 & 0.25 & 1.10 \\
\hline $19: 05$ & 299 & 4.0 & 459 & 6.70 & 9.0 & 144 & 183 & 0.25 & 1.10 \\
\hline $11: 10$ & $29 i$ & 4.0 & 462 & 6.70 & 85.0 & 141 & 179 & 0.24 & 1.11 \\
\hline $11: 15$ & 211 & 4.0 & 462 & 6.60 & 78.0 & 161 & 17 & 0.24 & 1.10 \\
\hline $11: 20$ & 211 & 4.0 & 440 & 7.20 & 71.0 & 150 & 197 & 0.27 & 1.09 \\
\hline VGS: & 211 & 4.0 & 455 & 6.80 & 94.9 & 145 & 185 & 0.25 & 1.10 \\
\hline
\end{tabular}

(1) Unit land recorded from control board.

(2) Average boiler 02, recordod from control board.

(3) Measurment of duct 502 , dry basis, BHEL, LAND-COM.

(4) Meseurement of duet 02, dry besis, TVA, TELEDYME.

(5) Messurement of $\mathrm{CO}$, Ppm, dry basis, BHEL, LND-COM.

(6) Mesaurciant of MOX, Ppm, dry besie, CPRI, SHIMUDZU.

(7) wox ppo corrected to $3 \times 02$.

(8) Enission rate, MOx, Ib/maTU, celculoted from duct wox measurements.

(9) Enission rote, s02, Ib/matu, calculated from duct s02 measureants. 
VIJAYAMADA PLANT TEST DATA

206 MM, 20\% EXCESS AIR, FAD 5\% OPEN, F 2 FF DAMPER OPEN

TEST 8

DATE : $2 / 8 / 92$

\begin{tabular}{|c|c|c|c|c|c|c|c|c|c|}
\hline Tive & $\begin{array}{l}\text { (1) } \\
\operatorname{Lan}\end{array}$ & $\begin{array}{l}\text { (2) } \\
\text { BOILER } \\
\text { O2X }\end{array}$ & $\begin{array}{c}\text { (3) } \\
802 \\
p=m, d r y\end{array}$ & $\begin{array}{l}(4) \\
02 \\
x, d r y\end{array}$ & $\begin{array}{c}\text { (5) } \\
\infty \\
p p m, d r y\end{array}$ & $\begin{array}{l}\text { (6) } \\
\text { mox } \\
\text { Ppon,dry }\end{array}$ & $\begin{array}{c}\text { (7) } \\
\text { mox ppm } \\
\text { e3x o2 }\end{array}$ & $\begin{array}{c}\text { (8) } \\
\text { mox } \\
\text { Ib/mbtu }\end{array}$ & $\begin{array}{c}(9) \\
902 \\
\text { lo/ibtu }\end{array}$ \\
\hline $12: 20$ & 206 & 3.3 & - & 7.10 & • & 128 & 166 & 0.23 & • \\
\hline $12: 25$ & 206 & 3.3 & $\star$ & 7.10 & • & 125 & 162 & 0.22 & $\star$ \\
\hline $12: 30$ & 206 & 3.3 & $\bullet$ & 7.10 & - & 127 & 164 & 0.23 & $*$ \\
\hline $82: 35$ & 206 & 3.3 & $\bullet$ & 7.10 & • & 128 & 166 & 0.23 & $\bullet$ \\
\hline $12: 40$ & 206 & 3.3 & - & 7.00 & • & 129 & 166 & 0.23 & $\star$ \\
\hline $12: 46$ & 206 & 3.3 & $\bullet$ & 7.00 & $\bullet$ & 139 & 168 & 0.23 & $\bullet$ \\
\hline $12: 50$ & 206 & 3.3 & $\star$ & 6.90 & $\bullet$ & 129 & 165 & 0.23 & • \\
\hline $12: 55$ & 206 & 3.3 & 438 & 7.10 & 108.0 & 134 & 174 & 0.24 & 1.08 \\
\hline $13: 00$ & 206 & 3.3 & 440 & 7.10 & 81.0 & 134 & 174 & 0.24 & 1.00 \\
\hline $13: 05$ & 206 & 3.3 & 435 & 7.20 & 70.0 & 137 & 179 & 0.25 & 1.08 \\
\hline $93: 10$ & 206 & 3.3 & 436 & 7.20 & 68.0 & 937 & 179 & 0.25 & 1.08 \\
\hline $13: 15$ & 206 & 3.3 & 429 & 7.40 & 62.0 & 141 & 187 & 0.26 & 1.08 \\
\hline AVGS: & 206 & 3.3 & 438 & 7.05 & 108 & 129 & 166 & 0.23 & 1.08 \\
\hline
\end{tabular}

(1) Unit land recorded from control board.

(2) Average boller 02, recordad from control board.

(3) Heesurcment of duct s02, dry basis, BMEL, LANo-con.

(4) Meosurement of duct 02, dry basis, TVA, TELEDYME.

(5) Measurement of $\mathrm{CO}$, Ppon, dry besis, BHEL, LAND-con.

(6) Heasurement of MOX, Ppm, dry basis, CPRI, SHIMnDZU.

(7) Wox ppo corrected to $3 \times 02$.

(8) Enission rate, MOx, Ib/mstu, calculated from duct wox messurements.

(9) Enission rate, s02, Ib/werU, calculated from duct 502 mesuraments.

(*) NO DATA RECORDEO 
VIJAYAWADA PLAMT TEST DATA

187 M, 25X EXCESS AIR, TYPICAL FAD, F \& FF DAMERS OPEN

DATE : $2 / 8 / 92$

\begin{tabular}{|c|c|c|c|c|c|c|c|c|c|}
\hline TIME & $\begin{array}{l}(1) \\
\operatorname{LOND}\end{array}$ & $\begin{array}{l}\text { (2) } \\
\text { DOILER } \\
\text { O2X }\end{array}$ & $\begin{array}{c}\text { (3) } \\
802 \\
p p, d r y\end{array}$ & $\begin{array}{l}(4) \\
02 \\
x, d r y\end{array}$ & $\begin{array}{c}\text { (5) } \\
\infty \\
p \text {,dry }\end{array}$ & $\begin{array}{l}\text { (6) } \\
m 0 x \\
\text { pin,dry }\end{array}$ & $\begin{array}{c}\text { (7) } \\
\text { nox ppo } \\
\text { e3x o2 }\end{array}$ & $\begin{array}{c}\text { (B) } \\
\text { mox } \\
\text { lb/mbtu }\end{array}$ & $\begin{array}{c}\text { (9) } \\
802 \\
\text { Ib/mbtu }\end{array}$ \\
\hline$: 15$ & 187 & 4.3 & - & 8.00 & 88.0 & 186 & 258 & 0.35 & 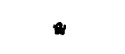 \\
\hline $16: 21$ & 187 & 4.3 & - & 8.10 & 83.0 & 181 & 253 & 0.35 & $\bullet$ \\
\hline $16: 25$ & 187 & 4.3 & $\bullet$ & 8.10 & 78.0 & 178 & 248 & 0.34 & • \\
\hline $14: 30$ & 187 & 4.3 & $\bullet$ & 8.60 & 80.0 & 203 & 295 & 0.40 & - \\
\hline $16: 35$ & 187 & 4.3 & - & 7.80 & 73.0 & 201 & 274 & 0.38 & - \\
\hline $14: 40$ & 187 & 4.3 & $\bullet$ & 7.60 & 71.0 & 203 & 273 & 0.37 & • \\
\hline $14: 45$ & 187 & 4.3 & $\bullet$ & 8.00 & 78.0 & 220 & 305 & 0.42 & • \\
\hline $16: 50$ & 187 & 4.3 & $\bullet$ & 7.50 & 52.0 & 168 & 224 & 0.31 & • \\
\hline $14: 55$ & 187 & 4.3 & $\star$ & 7.10 & 50.0 & 169 & 219 & 0.30 & • \\
\hline $15: 00$ & 187 & 4.3 & $\bullet$ & 7.40 & 67.0 & 208 & 275 & 0.38 & - \\
\hline AVGS: & 187 & 4.3 & • & 7.82 & 72.0 & 192 & 262 & 0.36 & • \\
\hline
\end{tabular}

(1) Unit laed recorded from control board.

(2) Average boller 02, recordad from control board.

(3) Measurement of duct SO2, dry basis, BHEL, LND-COA.

(4) Measurement of duct O2, dry besis, TVA, TELEDYME.

(5) Measurcoint of Co, Ppan, dry basis, BHEL, LAND-COM.

(6) Measurement of MOx, Ppm, dry basis, CPRI, SHIMUDZU.

(7) wox ppon corrected to $3 \times 02$.

(8) Enission rate, MOx, Ib/mBTU, calculated from duct mOx meseurements.

(9) Enission rate, 502 , Ib/msru, calculated from duct so2 measurcants.

(*) IO USUABLE DATA RECORDED 
VIJAYAMADA PLANT TEST DATA

185 M, 25\% EXCESS AIR, FAD 5X OPEN, F I FF DAMPERS OPEN

\begin{tabular}{|c|c|c|c|c|c|c|c|c|c|c|}
\hline $\begin{array}{l}\text { TEST } 10 \\
\text { DATE: } 2 / 8 / 92\end{array}$ & TIME & $\begin{array}{l}\text { (1) } \\
\text { LOND } \\
\text { and }\end{array}$ & $\begin{array}{c}\text { (2) } \\
\text { DOILER } \\
\text { OXX }\end{array}$ & $\begin{array}{c}\text { (3) } \\
502 \\
\text { pom,dmy }\end{array}$ & $\begin{array}{l}\text { (4) } \\
02 \\
x, d r y\end{array}$ & $\begin{array}{c}\text { (5) } \\
\infty \\
\text { prim,dry }\end{array}$ & $\begin{array}{l}\text { (6) } \\
\mathrm{mox} \\
\mathrm{min}, \mathrm{dry}\end{array}$ & $\begin{array}{c}\text { (7) } \\
\operatorname{mox} \text { ppin } \\
03 \% \text { o2 }\end{array}$ & $\begin{array}{c}\text { (8) } \\
\text { nox } \\
\text { Ib/mbtu }\end{array}$ & $\begin{array}{c}\text { (9) } \\
802 \\
\text { ib/mbtu }\end{array}$ \\
\hline & $06: 05$ & 185 & 4.6 & 334 & 8.20 & 94.0 & 154 & 217 & 0.30 & 0.90 \\
\hline & 06:10 & 185 & 4.6 & 336 & 8.20 & 86.0 & 156 & 219 & 0.30 & 0.90 \\
\hline & $06: 15$ & 185 & 4.6 & 341 & 8.10 & $\pi .0$ & 155 & 296 & 0.30 & 0.91 \\
\hline & O6:20 & 185 & 4.6 & 343 & 8.20 & $\mathbf{7 2 . 0}$ & 156 & 219 & 0.30 & 0.92 \\
\hline & $06: 25$ & 185 & 4.6 & 344 & 8.30 & 67.0 & 157 & 223 & 0.31 & 0.93 \\
\hline & $06: 30$ & 185 & 4.6 & 340 & 8.50 & 70.0 & 168 & 242 & 0.33 & 0.93 \\
\hline & 06:35 & 185 & 4.6 & 355 & 8.10 & 58.0 & 154 & 215 & 0.29 & 0.94 \\
\hline & $06: 40$ & 185 & 4.6 & 370 & 7.60 & 56.0 & 165 & 222 & 0.30 & 0.95 \\
\hline & AVGS: & 185 & 4.6 & 345 & 8.15 & 72.5 & 158 & 221 & 0.30 & 0.92 \\
\hline
\end{tabular}

(1) Unit load recorded from control board.

(2) Average boiler 02, recorded from control board.

(3) Measurement of duct s02, dry basis, BHEL, LANo-con.

(6) Measurement of duct 02, dry besis, TVA, TELEDYME.

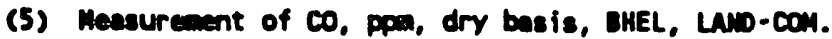

(6) meseurement of wOx, Ppa, dry basis, CPRI, SHImuDzU.

(7) nox pom corrected to $3 x 02$.

(8) Eniseion rate, wox, Ib/mstu, calculated from duct wox measuraments.

(9) Enission rate, 502 , Ib/m3TU, calculated from duct 502 measurements. 
VIJAYAGADA PLAN TEST DATA

$181 \mathrm{~m}, 15 \%$ EXCESS AIR, TYPICAL FAD, F I FF DAMPERS OPEN

TEST 11

DATE: $2 / 8 / 92$

\begin{tabular}{|c|c|c|c|c|c|c|c|c|c|}
\hline TINE & $\begin{array}{l}(1) \\
\text { LOND }\end{array}$ & $\begin{array}{c}\text { (2) } \\
\text { DOILER } \\
\text { OZX }\end{array}$ & $\begin{array}{c}\text { (3) } \\
\operatorname{sez} \\
p \operatorname{pom} d r y\end{array}$ & $\begin{array}{l}(4) \\
02 \\
x, d r y\end{array}$ & $\begin{array}{c}\text { (5) } \\
\infty \\
P . d r y\end{array}$ & $\begin{array}{c}\text { (6) } \\
m 0 x \\
\text { pim.dmy }\end{array}$ & $\begin{array}{c}\text { (7) } \\
\text { wox ppm } \\
\text { e3x } 02\end{array}$ & $\begin{array}{c}\text { (8) } \\
\text { nox } \\
\text { (b/mbtu }\end{array}$ & $\begin{array}{c}\text { (9) } \\
s 02 \\
\text { lb/rotu }\end{array}$ \\
\hline $9: 10$ & 181 & 2.9 & 383 & 7.00 & 24.0 & 172 & 221 & 0.30 & 0.94 \\
\hline $19: 15$ & 181 & 2.9 & 382 & 7.00 & $\pi .0$ & 174 & 224 & 0.31 & 0.94 \\
\hline $19: 20$ & 181 & 2.9 & 393 & 6.70 & 62.0 & 162 & 204 & 0.28 & 0.96 \\
\hline $19: 25$ & 181 & 2.9 & 391 & 6.80 & 55.0 & 167 & 212 & 0.29 & 0.94 \\
\hline $19: 30$ & 181 & 2.9 & 389 & 6.90 & 52.0 & 171 & 218 & 0.30 & 0.95 \\
\hline $19: 35$ & 181 & 2.9 & 307 & 7.00 & 49.0 & 173 & 222 & 0.30 & 0.95 \\
\hline $19: 40$ & 181 & 2.9 & 403 & 6.60 & 64.0 & 158 & 198 & 0.27 & 0.96 \\
\hline IVGS: & 181 & 2.9 & 390 & 6.86 & 63.3 & 168 & 214 & 0.29 & 0.95 \\
\hline
\end{tabular}

(1) Unit lasd recorded from control board.

(2) Averege boiler 02, recordad from control board.

(3) Massurement of duct 502 , dry basis, BHEL, LAND-CON.

(4) Mesaurament of duct 02, dry basis, TVA, TELEDYME.

(5) Measurement of CO, Ppon, dry besis, BHEL, LAND-CON.

(6) mesegurcaint of Mox, Ppon, dry beais, CPRI, SHIMuDZU.

(7) MOx ppom corrected to $3 \times 02$.

(8) Enission rote, Mox, Ib/waTu, calculoted from duct mox masuraments.

(9) Enission rate, 502 , (b/maTu, calculated from duct 502 maseurements. 
VIJAYAWADA PLANT TEST DATA

185 w. 15X EXCESS AIR, FAD 5X OPEN, F \& FF DAMPERS OPEN

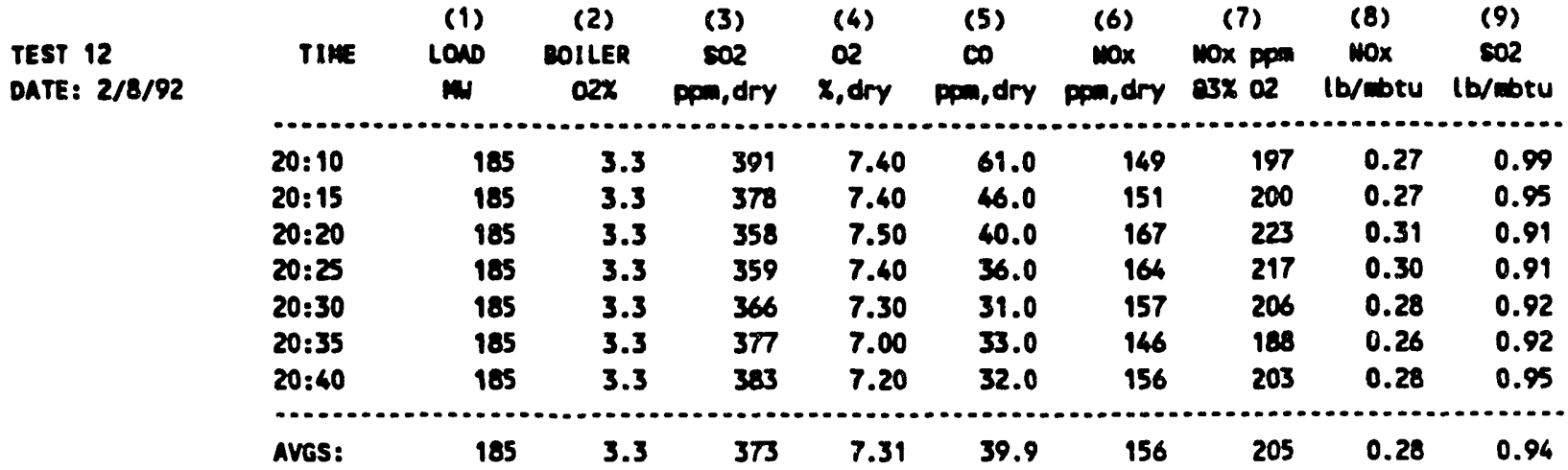

(i) Unit load recordad from control bourd.

(2) Average boiler 02, recorded from control board.

(3) Measurement of duct 502 , dry basis, BHEL, LAND-COM.

(6) Messurement of act Q2, dry besis, TVA, TELEDYME.

(5) Measurement of CO, ppon, dry besis, BHEL, LAND-CON.

(6) Mesesurement of MOx, Ppa, dry basis, CPRI, SHIMMDZU.

(7) Wox ppo corrected to $3 \times 02$.

(7) Eaission rate, MOx, Ib/maTU, calculated from duct $n 0 x$ messurements.

( (8) Enission rate, $502, \mathrm{lb} / \mathrm{mBTU}$, calculated from duct 502 messurements. 
VIJAYAMAD PLANT TEST DATA

172 . $20 \%$ EXCESS AIR, TYPICAL FAD, F \& FF DAMPERS CLOSED

\begin{tabular}{|c|c|c|c|c|c|c|c|c|c|c|}
\hline $\begin{array}{l}\text { TEST } \& X \\
\text { DATE: } 2 / 7 / 92\end{array}$ & TIME & $\begin{array}{l}(1) \\
\operatorname{Lan} \\
\ln \end{array}$ & $\begin{array}{l}\text { (2) } \\
\text { DOILER } \\
\text { O2X }\end{array}$ & $\begin{array}{c}\text { (3) } \\
s 02 \\
P=, d r y\end{array}$ & $\begin{array}{l}(4) \\
02 \\
x, d y\end{array}$ & $\begin{array}{c}\text { (5) } \\
\infty \\
p=0, d m y\end{array}$ & $\begin{array}{c}\text { (6) } \\
m 0 x \\
p p, d r y\end{array}$ & $\begin{array}{c}\text { (7) } \\
\text { nox ppo } \\
\text { obx o2 }\end{array}$ & $\begin{array}{c}\text { (8) } \\
\text { wox } \\
\text { ib/cbtu }\end{array}$ & $\begin{array}{c}\text { (9) } \\
802 \\
\text { Ib/ubtu }\end{array}$ \\
\hline & $23: 31$ & 172 & 3.7 & 504 & 7.10 & 131.0 & 174 & 225 & 0.31 & 1.24 \\
\hline & $23: 35$ & 172 & 3.7 & 508 & 7.00 & 117.0 & 166 & 213 & 0.29 & 1.25 \\
\hline & $23: 40$ & 172 & 3.7 & 502 & 7.10 & 115.0 & 173 & 224 & 0.31 & 1.24 \\
\hline & $23: 45$ & 172 & 3.7 & 503 & 7.10 & 908.0 & 17 & 229 & 0.31 & 1.26 \\
\hline & $23: 50$ & 172 & 3.7 & 502 & 7.00 & 102.0 & 176 & 226 & 0.31 & 1.23 \\
\hline & $23: 55$ & 172 & 3.7 & 501 & 7.10 & 98.0 & 176 & 228 & 0.31 & 1.24 \\
\hline & $00: 00$ & 172 & 3.7 & 501 & 7.00 & $\boldsymbol{M . 0}$ & 175 & 225 & 0.31 & 1.23 \\
\hline & $00: 05$ & 172 & 3.7 & 501 & 7.10 & 92.0 & 175 & 227 & 0.31 & 1.24 \\
\hline & AVGS: & 172 & 3.7 & 503 & 7.06 & 107.1 & 174 & 225 & 0.31 & 1.24 \\
\hline
\end{tabular}

(1) Unit laod recordad from control board.

(2) Average boiler 02, recorded from control board.

(3) Measurement of duct 502, dry basis, BHEL, LAHO-COM.

(4) Measuresent of duct 02 , dry basis, TVA, TELEDYME.

(5) Mensurament of $\infty$, ppom, dry besis, BHEL, LAND-con.

(6) Measurement of wOx, ppon, dry besis, CPRI, SHIMnDZU.

(7) Nox ppm corrected to 3x 02.

(8) Enission rate, wOx, Ib/mBT, calculated from duct mox masurements.

(9) Emission rate, 202 , lb/m3TU, calculated from duct 502 masurements. 

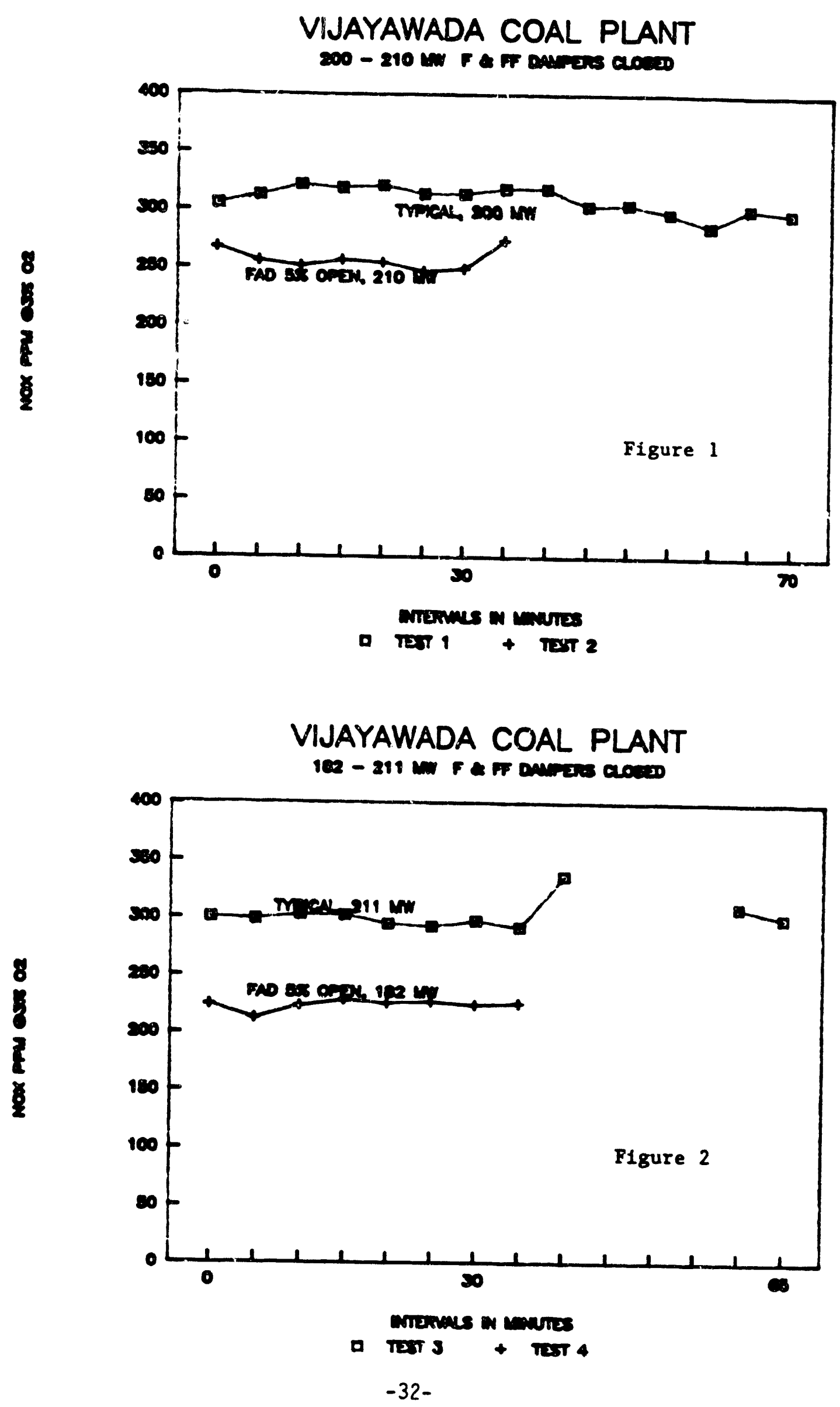

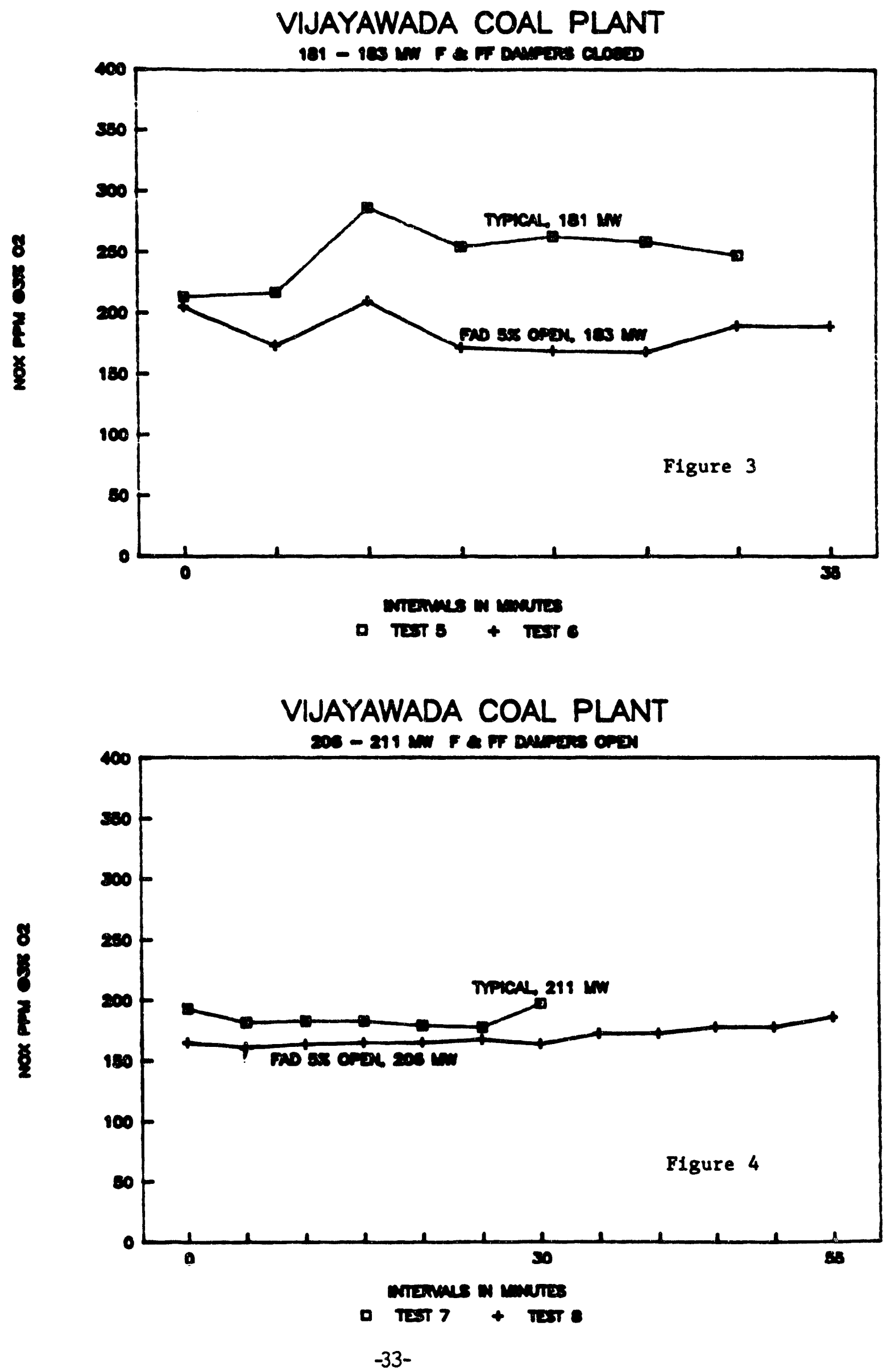

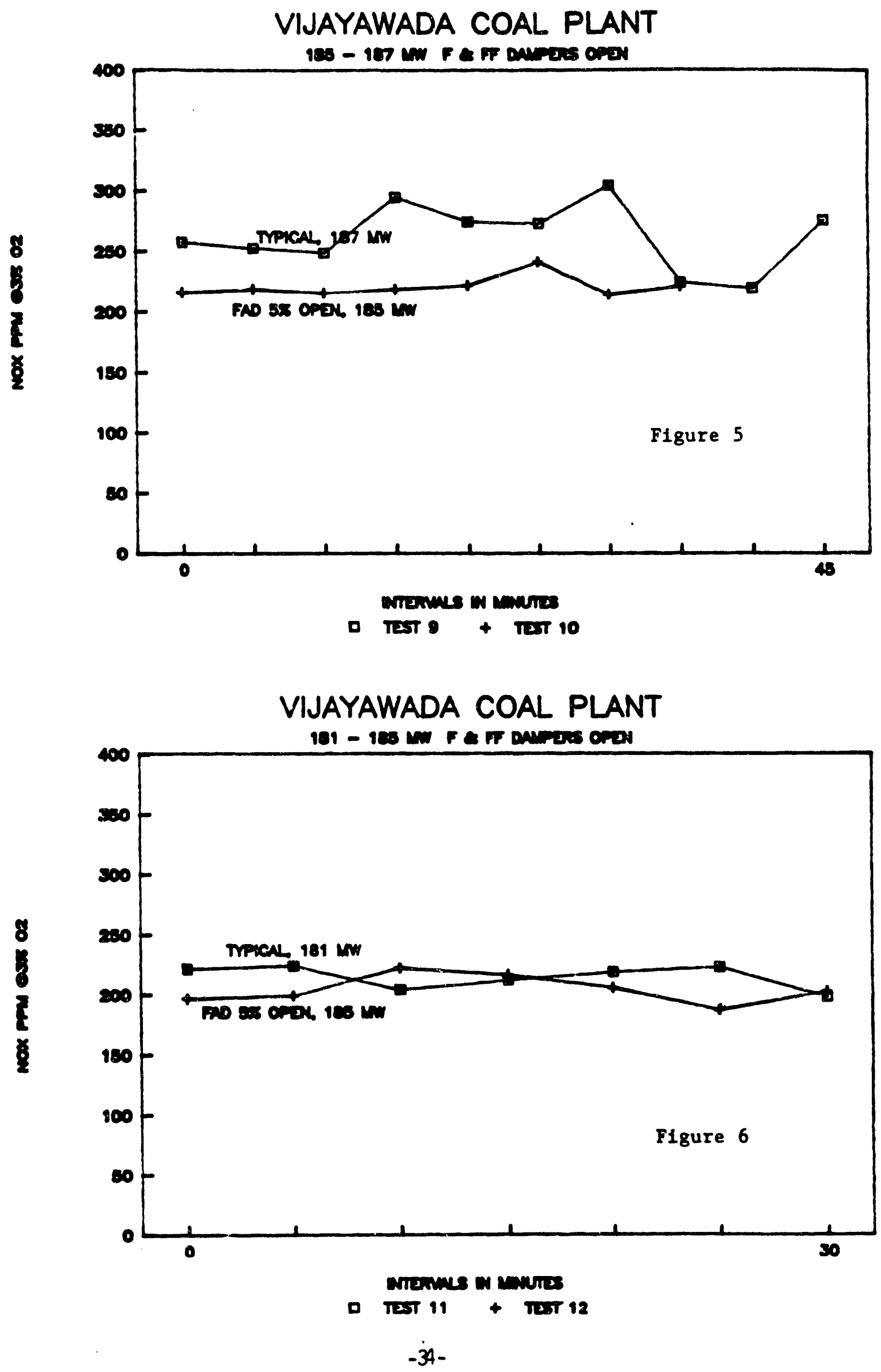

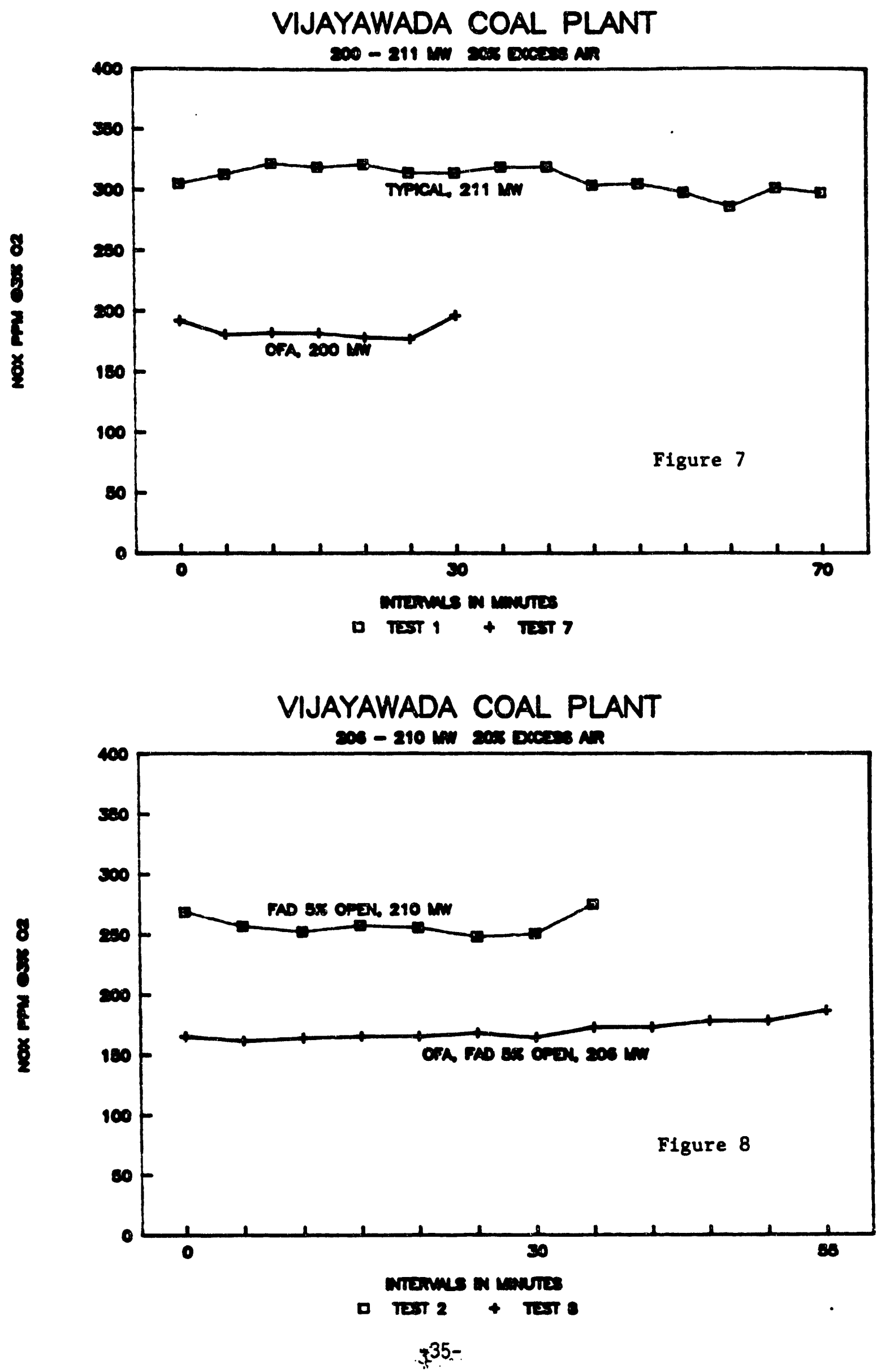

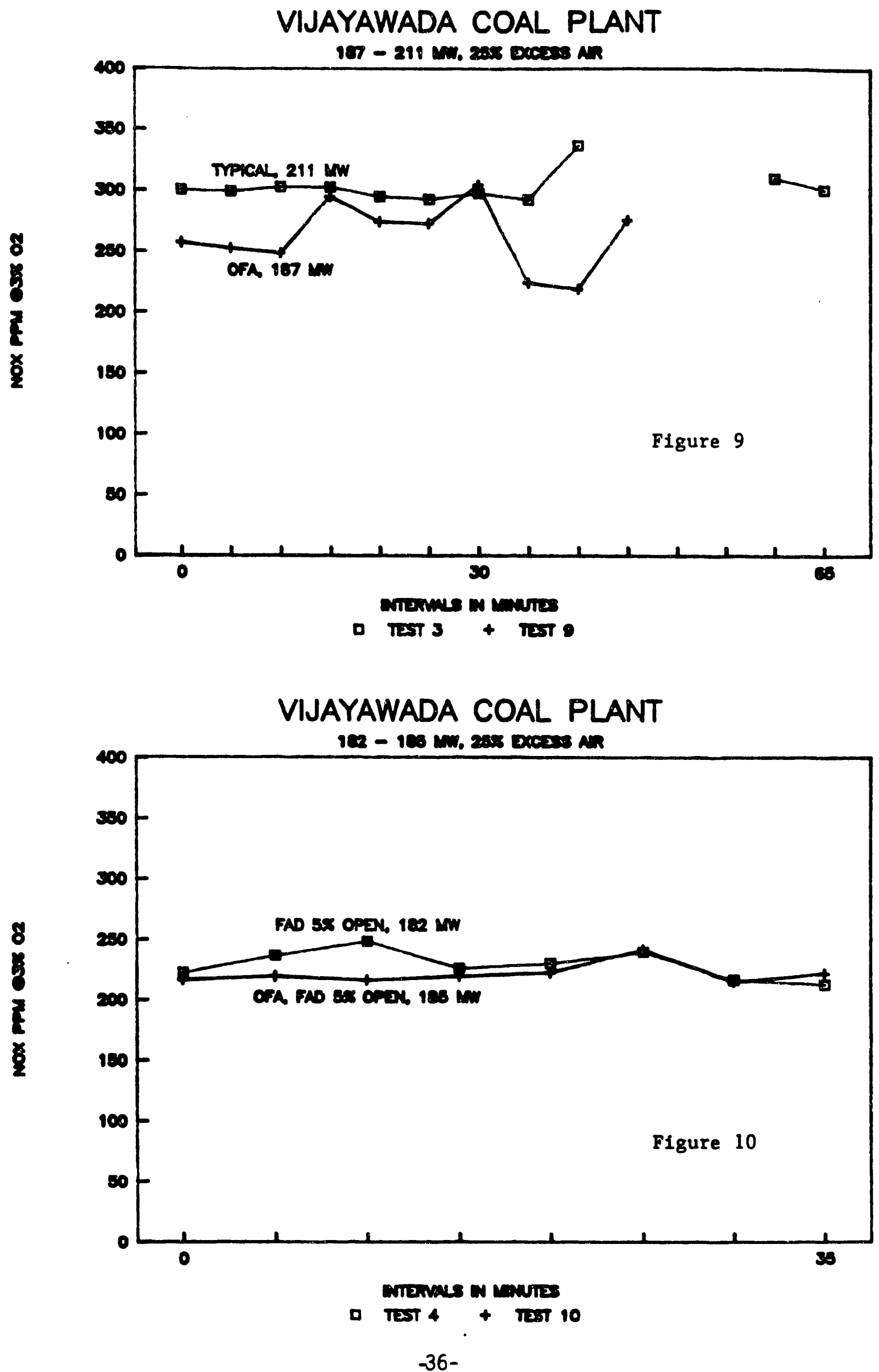

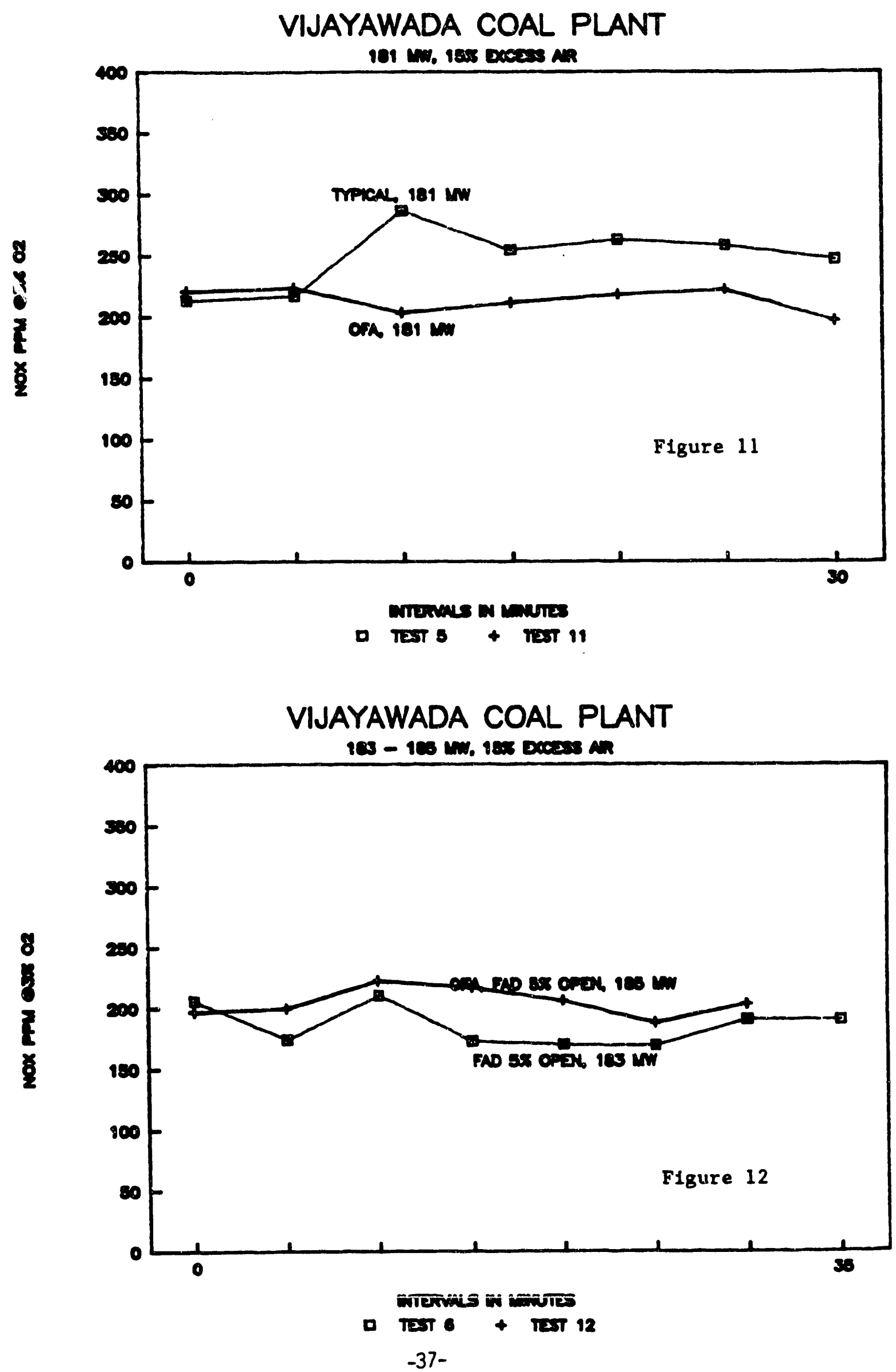


\author{
Report of Foreign Travel to India by \\ Blaine W. Roberts During the Period February 9 - March 7, $19: 2$ \\ Tennessee Valley Authority \\ Plant Technical Services \\ 1101 Market Street \\ Chat tanooga, Tennessee 37402-2801
}

May 25, 2992

\title{
PURPOSE
}

At the request of the Pittsburgh Energy Technology Center (PETC) and the U.S. Department of Energy (USDOE), technical assistance was provided to Bharat Heavy Electricals Ltd. (BEEL), Trichy, India, in the imp'scentation of the United States Agency for International Development (USAID)/Government of India (GOI) collaborative coal profects at BBEL, Trichy. The specific activities scheduled for this trip were: (1) perform a life assessment of the boiler and selected auxiliaries at the Nasik Thermal Power Station (NTPS), jointly with BHEL and a team of three other U.S. experts from APTECB Engineering Services and Failure Analysis Associates (FAA); (2) make a presentation in the one-day workshop on Life Bxtension Studies in Thermal Power Plants organized by the Power Finance Corporation (PFC) in New Delhi, India; (3) advise the PFC on structuring the work statement for the life extension demonstration model studies to be carried out under the recently initiated USAID/GOI Energy Management Consulting and Training (EMCAT) project, and; (4) provide on-site review and evaluation to BHEL, Trichy of the completed life extension activities at NTPS. Dr. William C. Peters with the USAID coal program at PETC participated in all the activities except the concluding review at BHEL, Trichy, and Dr. R.P. Rrishnan with Martin Marietta Energy Systems, Inc. at Oak Ridge National Laboratory (ORNL) participated in all activities.

The four USA. experts, their affiliation, and general areas of responsibility for the NTPS life extension study are as follows:

Blaine W. Roberts Tennessee Valley Authority

Laney H. Bisbee

Failure Analysis Associates

Eric V. Sullivan

APTECH Engineerings Services

Marvin J. Cohn
APTECH Engineering Services
Team Leader with General Responsibility for the Bigh-Temperature Boiler Components.

Non-Destructive Testing In General and Evaluation of High-Temperature Boiler Beaders

Measurement of Oxide Scale Thickness of Superheater and Reheater Boiler Tubing to Estimate Remaining Useful Life

Evaluation of the Main Steam and Bot Reheat Piping Systems 
The remainder of this trip report will be organized as a chronological record for the major activities which were performed.

TRAVEL FROM U.S.A. TO INDIA

Departure was from Chattanooga, TN at 3:15PM on February 9, 1992 with arrival in Frankfurt, Germany at 7:50AM on February 10, 1992. There was a one-day layover in Frankfurt, Germany with departure at 12:00 Noon on February 11, 1992 and arrival in Bombay, India at 1:10AM on February 12, 1992. Mr. C.R. Raju of BHEL, Trichy met me at the airport and accompanied me to the Searock Hotel in Bombay.

\section{BOMBAY ACTIVITIES}

I met with Dr. William C. Peters, PETC, and Mr. Laney B. Bisbee, FAA, who had arrived in India earlier. They had been engaged in getting the non-destructive examination (NDE) equipment, which had been shipped from FAA to India, through customs. Mr. Marvin J. Cohn and Mr. Eric V. Sullivan, APTECH, arrived later in the day on February 12, 1992. The plan to depart for Nasik, India by automobile on February 13, 1992 was reviewed.

On February 13, 1992, the team met with the following BHEL, Trichy personnel involved in the NTPS study:
Mr. N. Ayodhi
Mr. C.R. Raju
Mr. Jainender Kumar
Manager, Field Engineering Services
Manager, Research and Development
Manager, Field Engineering Services

Mr. Kumar's main responsibilities were securing of equipment clearance through customs, securing accommodations in Nasik, India, and getting the work properly initiated at the NTPS. Mr. Ayodhi and Mr. Raju were the key technical coordinators for the BHEL, Trichy team.

The USA and BHEL team departed Bombay on February 13, 1992 by automobile in late afternoon and arrived in the city of Nasik the same evening. Accomodations were arranged at the Holiday Plaza Hotel. The drive to the NTPS was about 30 minutes from the hotel.

\section{NASIK THERMAL POWER STATION}

Eebruary 14. 1992 - The team met with the following NTPS personnel who would act as major contacts for the duration of the project:
Mr.R.G. Patil
Chief Engineer
Mr. D.Y. Ghenekar
Deputy Chief Engineer
Mr. G.B. Shedji
Superintendent Engineering

We were also introduced to 13 other BHEL support people who were on-site to provide NDE, field replication, and boiler inspection services for the condition assessment. 
During the orientation, it was explained that the NTPS has five units. Units 1 and 2 are each rated at $140 \mathrm{MW}$ and were commissioned on August 16, 1970 and March 21,1971 respectively. Units $3-5$ are each rated at $210 \mathrm{MW}$ and were commissioned on April 26, 1979, July 10, 1980, and January 30, 1981 respectively. The unit which had been previously selected for the condition assessment was Unit 2 .

At the time of the outage, Unit 2 had operated for 132,734 hours. The last boiler overhaul was February 14, 1989 and the last turbine overhaul was March 9, 1989. No turbine work was scheduled during the current outage.

The Unit 2 boiler is a balanced draft, natural circulation, two pass, dry bottom design supplied by Babcock and Wilcox, France. Four B\&W EM90 type coal mills feed at four elevations to the sixteen burners located in the front wall of the boiler. The unit is designed to supply main steam and hot reheat at a temperature of $540^{\circ} \mathrm{C}\left(1004^{\circ} \mathrm{F}\right)$ with main steam pressure of $145 \mathrm{~kg} / \mathrm{sq} \mathrm{cm}(2060$ psi) and reheat pressure of $35 \mathrm{~kg} / \mathrm{sq} \mathrm{cm}$ (500 psi).

The superheater section consists of a primary superheater located in the second pass. The secondary radiant superheater and the convection superheater are of pendant design. Superheat temperature control is achieved by water injection. The location of the injection nozzle is between the primary superheater outlet header and the secondary radiant superheater inlet header.

The reheater is of pendant design with a cross-flow arrangement. Reheat steam temperature control is primarily by gas recirculation. Water injection for reheat temperature control is intended only for low load operation. Water injection is upstream of the reheat inlet header. Soot blowers of the retractable type are provided in the furnace and long retract blowers are provided in the superheater and reheater sections. An electrostatic precipitator is provided at the air heater outlet for particulate emissions control. The air heater is a Ijungstrom regenerative type.

The design coal is 9 percent moisture, 20 percent ash, and 22 percent volatile matter with a higher heating value (HBV) of $5800 \mathrm{kcal} / \mathrm{kg}$. However, the coal burned in the plant has deteriorated with time and is now typically 40 percent ash and only 3400-3800 kcal/kg BHV.

The flue gas temperature leaving the boller is around $160^{\circ} \mathrm{C}\left(320^{\circ} \mathrm{F}\right)$ which is higher than the design temperature. The frequency of operation of the wall blowers is once each 8 hour shift and twice a week for the long retractable blowers.

The plant personnel reported that there had been repeated failures in the primary superheater coils, reheat inlet and outlet header stub welds, and tube thinning in the economizer section due to gas-side erosion. After completion of the orientation and general review, the team performed a walk-through of Unit 2 including entry into the penthouse to examine the work being performed to prepare the headers for inspection. A leaking reheat inlet header stub tube weld was detected by the flow of air while in the penthouse. At the end of the day, the USA/BHEL team met with Mr. R.G. Patil, who is the equivalent of Plant Manager for all five units, for a review of work plans and schedule. Mr. Patil emphasized that the plant would lend full support but the outage was limited to 35 days and the team had about 10 days to complete the examinations. 
Februacy 15-17, 1922 - The detailed planning on tube sample removal, replica sites on the headers and piping, headers for video boroscopic examination, and tubes for oxije scale measurement was completed and the work initiated. The supporting staff preparing the inspection sites worked around the clock. The USA/BHEL team wes joined by the BHEL overall coordinator, Dr. S. Gourishankar, who is Senior Manager in Research and Development, during this period.

The major finding during this period was the discovery of serious erosion in the RH inlet header bore holes which was found when some of the tubes were removed near the stub weld for subsequent laboratory analysis. The steam to the RH inlet header enters through a center tee. The tube rows directly opposite the inlet tee, Rows 41-43, had very little erosion but Rows $36-40$ and 44-48, which were symmetrically located on either side of the tee, had significant erosion of the bore holes, mostly confined to the area near the header inside diameter. The leak, previously found on the teams first entry into the penthouse, resulted from the severe erosion.

The erosion appeared to have resulted from water impingement. In reviewing plant operation, it was found that exceptionally high use of RH attemperator spray was required to control $\mathrm{RH}$ outlet temperature due to the decline in coal heating value and high ash content. A check of the strip chart for the period prior to shutdown showed the temperature upstream of the attemperator to be $320^{\circ} \mathrm{C}\left(608^{\circ} \mathrm{F}\right)$ while the temperature downstream was $220^{\circ} \mathrm{C}\left(428^{\circ} \mathrm{F}\right)$. This $100^{\circ} \mathrm{C}$ $\left(180^{\circ} \mathrm{F}\right)$ drop in temperature by the attemperator is far outside the intended operational envelope and is the direct consequence of deteriorating coal quality. It was rationalized that water droplets were entering the $R B$ inlet header due to either an inadequate mixing length for the quantity of water being injected or, potentially, because the opray reduced the temperature below the saturation point. The accuracy of plant instrumentation was not sufficient to determine whether the mixture was below saturation. In any event, it was certain that water droplets were entering the RH inlet header which was then acting as a molsture separator and experiencing erosion on those tubes where a large change in flow direction was required. So far as any of the participants knew, this phenomena had never been previously reported by other utilities.

February 18-21. 1992 - The video boroscopic examination of the following headers was completed during this period:

- Reheat Inlet Header

- Reheat Attemperator

- Reheat Outlet Header

- Primary Superheat Outlet Header

- Secondary Superheater Outlet Header

- Main Steam Attemperator

- Economizer Inlet Header

The erosion damage previously described for the RH inlet header was confirmed and the extent of damaged rows defined by the video boroscopic examination. These results naturally gave cause for concern for the attemperator and elbow between the attemperator and inlet tee. The boroscopic inspection of the $\mathrm{RH}$ attemperator showed cracking in the weld securing the liner to the pipe upstream of the injection nozzle and a region of circumferential cracking in the liner downstrean from the nozzle. Bowever, the 1 iner was intact and in 
the proper position. The injection nozzle itself suffered from severe erosion in the plate opposite the nozzle outlet. The elbow downstream from the flow nozzle was examined by ultrasonics for possible cracking due to thermal shock but no evidence of cracking was found. However, a significant portion of the extrados of the elbow was found to be thinned by as much as 20 percent, apparently from the water impingement.

The RH outlet header has symmetry with the RH inlet header, with Row 42 being the central row. The plant had reported that weld repairs had been made to Rows 36-38 due to ligament cracks that had caused steam leaks. There was a mystery as to why Rows 46-48, which are symmetric, had not cracked. The non-symmetrical design of the entry piping and the anti-rotation devices vere examined for a possible explanation. However, the boroscopic examination revealed an advanced state of 1 igament cracking in Rows 46-48 with the expectation that steam leaks will eventually follow. Significantly, the tubes in the RH outlet beader experiencing the worse ligament cracks are fed by the tubes having the worse erosion on the RH inlet header. It is theorized that these tubes are globally cooler than the surrounding tubes, which produces a tensile thermal stress and ligament cracking during operation.

The primary SH outlet header was boroscopically examined by access through two holes in the central region. There was no evidence of cracking in the header. However, there was a whitish surface scale which was thought to be indicative of phosphate carryover from the drum to the prinary superheater. According to Mr. Ayodhi, the plant uses coordinated phosphate water treatment. Whatever the origin of the deposit, it apparently represents no threat to the header.

The secondary SH outlet header was examined boroscopically and revealed early stages of borehole cracking in several of the ligaments. The cracking was mostly confined to the header inside diameter to borehole edge with a preferred circumferential oriertation. A few of the ligaments showed hole-tc-hoie cracking on the inside surface but the cracks did not appear to be deep. This condition will need to be monitored periodically to assure it does not advance to a critical stage before header replacement is planned.

One of the two main steam attemperators was examined boroscopically. A region of minor cracking of the liner to header ring weld was detected but this was judged to be of no serious concern.

The economizer inlet header was examined boroscopically by gaining access through cut tubes in Rows 1,4 , and 12 . No header body or ligament cracking was detected. There was some surface pitting but the severity was judged to be of no consequence.

One other activity during this period was the removal of a small scoop sample at a main steam girth weld using the patented FAA small sample removal system. In this instance, the removal was more a demonstration of the equipment than a need identified by the examinations.

February 22. 1992 - This day was devoted to meetings between the USA/BHEL team and the plant staff to organize preliminary report of the findings for presentation to plant management in the exit meetings planned for February 24 , 1992. In addition to the previous participants, the team was joined by 
Mr. Robert Blumberg and Dr. N. V. Seshadri from USAID in New Delhi, India during this period.

February 23, 1992 - This was a day of leisure. The NTPS provided a tour bus and entertained the USA and BHEL guests with tours through the countryside and visits to the various religious shrines.

February 24, 1922 - The USA/BHEL team provided a summary of the oignificant results from the condition assessment including replays of relevant portions of the video tapes from the boroscopic examinations of the headers and at temperators. Some inspections were incomplete at the time and some laboratory examinations of tube samples remained to be completed. At tachment 1 , which was finalized on the visit to BHEL, Trichy, summarizes the results of the life extension activities.

Following the exit review, we departed Nasik and traveled by automobile to Bombay, arriving in the early evening with accommodations at the Searock Hotel.

\section{NEW DELHI - WORKSHOP AND OTHER ACTIVITIES}

February 25, 1992 - During the day in Bombay, I worked on the presentation for the seminar scheduled for February 27, 1992 in New Delhi. We departed from Bombay by air at 8:30PM and arrived in New Delhi at 10:20PM. Accommodations were at the Claridge Hotel. At the Claridge Hotel, the USA team was rejoined by Mr. Marvin J. Cohn who had been at BHEL facilities in Madras performing computer flexibility analyses of the piping systems and $\mathrm{Dr}$. William C. Peters who had been on another assignment in Bangalore.

February 26, 1992 - In the morning, the USA team members (Peters, Rrishnan, Roberts, Bisbee, Sullivan, and Cohn), Shedji (NTPS), and Seshadri (USAID) met with several members of the Power Finance Corporation including the following:

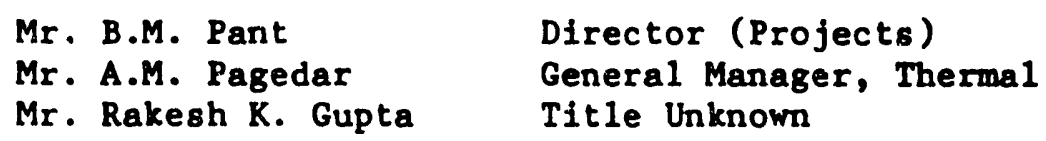

Mr. Pant reviewed the role of $P F C$ in arranging the finances for life extension activities in India. The funding for this work is split as 30 percent from the state electricity boards and 70 percent from PFC. About 16 units have been identified for life extension and 4 to 6 are targeted within the next year. The main "full service" organization within India is BHEL and PFC is interested in developing alternative organizations to supply services. PFC is working with USAID to identify USA companies with expertise to bring to the India market and transfer technology to internal organizations. PFC had previously sponsored two workshops on life extension similar to the one planned for February 27, 1992.

In the afternoon, accommodations were changed to Le Meridien Hotel. Later, a meeting involving the entire USA team and Shedji from NTPS was held at the USAID office. USAID participants included Blumberg, Seshadri, and Dr. John Aron Grayzel, Director of USAID for India. The US team showed slides illustrating the work performed at Vijaywada on SOX and NOX monitoring and the condition assessutent activities performed at Nasik. 
February 27. 1992 - The PFC organized a workshop on life extension studies in which there were approximately 80 attendees representing a vroad base of State Electricity Boards, USAID, BHEL, and other organizations providing services to the Indian utility market. Attachment 2 is the agenda for the meeting and Attachment 3 is a list of attendees. After introductory remarks from PFC and USAID, each of the four experts from the USA team made formal presentations based on extended abstracts which had been prepared prior to travel to India. Each presentation was followed by a brief period of questions and answers. There were three final presentations which focussed on specific life extension activities performed at power plants in India followed by anel discussion.

The facilities, audio-visual aids, organization, and conduct of the workshop were first-class. The question and answer period and the panel discussions provided a fruitful exchange with the attendees. In his role on the panel, Dr. Krishnan emphasized the impact of poor coal quality (high ash content and poor heating value) in a majority of the problems experienced by Indian power plants.

Eebruary 28, 1992 - A concluding meeting was held between the USA team (Peters, Krishnan, Roberts, Bisbee, Cohn, and Sullivan), PFC (Pant, Pagedar, Gupta, and others), and Mr. K. Natarjan, Director of the Central Electricity Authority. The purpose was to review in greater detail the work performed at Nasik. Highlights of the video boroscopic exams for the headers and attemperators were shown. Additionally, each USA participant reviewed their perspective on the work performed and of fered suggestions for follow-on work.

Eebruary 29 - March 1.1992 - These were days of leisure except for the departure for Madras at 8:15PM on March 1, 1992. Arrival in Madras was at 10:45PM with accommodations at the Trident Hotel. When traveling by air from New Delhi to Trichy, an overnight stay in Madras is necessary because of the paucity of flights.

\section{ACTIVITIES AT BHEL IN TRICHY}

March 2. 1992 - We departed Madras by air at 7:00AM and arrived in Trichy at $7: 45 \mathrm{AM}$. Accommodations in Trichy were in the BBEL guest house which is quite comfortable and has beautiful grounds. An introductory meeting was held with Mr. A.V. Narayanan, General Manager, Engineering and Comercial Coordination. In addition to Mr. Narayanan, most of the participants in the NTPS life extension project as vell as the following key staff members participated in the various meetings held at Trichy:
K.M.V. Malarkan
P.S. Subramanian
General Manager, Research and Development
V.G. Jagannath
M.N. Chandrasekharaiah
K. Padmanabhan
Manager, NDT
General Manager, Welding Research Institute
Senior Manager, Welding Research Institute
Manager, Welding Research Institute

In the afternoon, we toured the following BHEL R\&D facilities:

Direct Ignition of Pulverized Coal

Bubbling Bed Fluidized Bed Combustion Demonstration Project

Circulating Bed Fluidized Bed Combustion Demonstration Project

Welding Research Institute 
March 3. 1922 - Most of the day was spent touring the BHEL heavy vessel comercial manufacturing facility. This acility is well equipped ard appears to rival counterpart plants in the USA.

March 4. 1992 - A wrap-up meeting was held with Narayanan and stat $\bar{r}$. The final conclueisns of the NTPS activities were developed with Gourishankar and other participanis and are included as Attachment 1 to this report.

\section{TRAVEL FROM TRICBY TO THE USA}

We departed from Trichy by air to Madras on the moming of March 5, 1992. Because of a long iajover in Madras, accommodations were arranged at the Trident Hotel. Departure from Madras was at $11: 35 \% \mathrm{M}$ with arrival in London, UK at 5:40AM on March 6,1992. There was a one-dy layover in London with accommodations at the Sheraton, Heathrow. Departure from London was at 11:00AM on March 7, 1992 with arrival in Chattanooga, IN at 8:10PM the same day.

\section{GENERAL OBSERVATIONS}

The technical sumary of the work performed by BHEL and the USA team is contained in Attachent 1.

It is my opinion that any USA company seeking to establish a market with the electric generating utilities in India must have a strong Indian counterpart company. At the present stage of development, it appears to me that BBEL is the most viable Indian organization with expertise in Iffe extension. However, an alliance with BBEL is not perceived to he the most desirable goal by PFC. There may be other alternatives, but I believe an Indian company, which understands the unique cultural and comercial aspects of doing business in the country, will be an essential partner for a USA company. In general, Americans have simply not made a serious attempt to recognize the uniqueness of opportunities in India and develop long-term strategy to establish a credible presence. Wikhout doubt, there is a strong need for USA expertise in iffe extension projects in India, but it will require ingenuity for any USA company to develop a profitable niche. 
Attachment 1

Summary of Results From the Life

Assessment Activities at NTPS Unit 2

\section{BOILER DRUM}

Visual inspection of the boiler drum revealed the presence of magnetite coating on the inside of the drum. The drum internals were found to be in good condition. U1trasonic and magnetic particle inspection was performed on the circumferential seam welds of the dished ends and in the longitudinal welds for one meter from each end. No defects were detected and further examination was judged to be unwarranted. Oversight personnel from the Maharashtra State Electricity Board (MSEB) concurred with this decision. Drum deposits were collected for analysis and the results will be reported by bHEL in their final report.

\section{EURNACE}

Visual examination showed heavy deposition of cementitious material on the outside of the tubes. No bowing of water wajll tubes was noted. Checking of furnace tubes for hydrogen damage revealed none to be present. Sample tubes were collected for internal deposit analysis and the findings will be furnished by BHEL in the $f$ inal report.

\section{ECONOMIZER}

Erosion was observed in the straight portion of some assemblies and replacement is being carried out by MSEB. The economizer inlet header was examined using the video boroscope and no defects were seen. There was general water side corrosion which was not severe and posed no 1 imitation to operation of the header.

\section{RRIMARI SUPERHFATER}

Visual observation of the primhyy superheater coils showed good alignwent. Some deposition was seen at a fer locations on the outside surface. Tube samples were collected from the terminal tubes and from the horizontal portion of previously removed tubes. The analysis results will be reported by BHBL in the final report. Dimensional measursments were carried out on the inlet header which is in the gas pass. Thinning of the header on the outside surface due to flyash erosion from $42 \mathrm{~mm}$ to $28 \mathrm{~mm}$ wall thickness was observed. Gas side flow bypass baffles have been installed and should stop further erosion. However, close monitoring of the baffles is advised to be certain they are performing as expected.

The primary superheat outlet header was examined by video probe and no significant damage was observed. A white deposit was present in a few areas of the inside surface which was thought to be the result of phosphate carryover from the $d r, \mathrm{vm}$. A check for similar deposits was proposed by removal and examination of selected roof tubes. NDT of the stubwelds and butt uelds revealed no defects. 


\section{RADIANT SUPERHEATER}

Visual observation of the radiant superheater coils indicated good alignment and no evidence of overheating was seen. The tubes were coated with a heavy, adherent external deposit. It was recommended that the tubes be cleaned prior to restart.

\section{CONVECTION SUPRRBEATER}

Secondary superheater colls were found to be coated with heavy deposits. Alignment clamps had been severely oxidized at a few locations and should be replaced. The 17 the and 18 the assemblies from the left were bowed and distorted. These must be realigned or replaced prior to restart of the unit. Sample tubes from the outlet section were removed for metallurgical analysis and the results will be included in the BBEL final report.

The secondary superheater outlet header was examined by video probe. The early stages of ligament cracking was found on the inside surface. A fen of the ligaments showed hole-to-hole cracking on the inside surface but the cracks did not appear to be deep. No evidence of through-thickness borehole cracking was seen. Occasional monitoring of the liganent cracks is advised. NDE carried out on the stub welds and on the circumferential welds indicated no damage.

\section{REHEATER}

Visual observation of the inlet section of the reheater coils indicated good alignment. Dimensional measurements indicated metal wastage at the bottom portion of the coils just above the primary superbeater coil in the R4 zone. This wastage could be due to preferential gas flow due to misalignment of the coils and/or damaged refractory near the rear waterwall section. Necessary repairs are required before restart of the unit.

The video probe examination of the reheat inlet header inside surface revealed significant erosion at entry on about eight rows, four each on either ide of the inlet tee. This erosion is caused by water carryover from the spray to the reheat inlet. Metal vastage (20 percent thinning) was measured on the extrados of the elbow downstream from the spray. NDE of the header stubs and butt welds indicate damage was confined to the stub-header junction. Smoothing of the worse eroded areas and possible weld buildup is advised prior to restart. Alteration in boiler operation or the heat absorption pattern to lower the spray ueage is needed for a long-term solution.

Non-destructive examination was also carried out on on header stub welds and butt welds of the reheat outlet header. The examination indicated the welds to be in good condition. Ligament cracking in Rows 36, 37, and 38 had been previously weld repaired. The video probe examination revealed that the symmetrically located Rows 46,47 , and 48 also suffered from circumferential ligament cracking. The cracks were examined by ultrasonics and were found to be below the sizing 1 imit $(2.5 \mathrm{~mm})$ of the ultrasonic equipment. It is recommended that the cracked ligaments be ultrasonically examined at each major outage to estabiish the rate of crack growtin. 


\section{REHEAT ATTEMPERATOR}

Erosion was observed in the spray nozzle and severe metal $108 s$ had occurred in the back plate opposite the nozzle. A video probe examination showed severe multiple cracks on the weld between the liner and the fixing ring. Circumferential cracking of the liner downstream from the nozzle was also detected. Repaix or replacement of the liner at the earliest opportunity is recommended.

\section{MAIN STEAM ATTEYYPBRATOR}

Internal examination of the left main steam attemperator was carried out with the video probe. The liner was found to be intact but minor cracks vere observed in the weld between the liner and the fixing ring. Shallow pitting was observed on the diffuser portion of the liner. No immediate action is necessary but the liners should be reinspected periodically for possible growth of the crack in the weld.

\section{RIPING}

Hot and cold walkdown checks were done on main steam, cold reheat, and hot reheat piping. The hangers in the cold reheat and hot reheat piping were found to be loaded within the allowable range. A few hangers in the main steam line near the turbine were topped out. The seal plate on the main steam pipe at the penthouse exit point was cracked but there was no penetration of cracks into the pipe. After necessary stress calculations, hanger adjustments will be recommended if needed. 


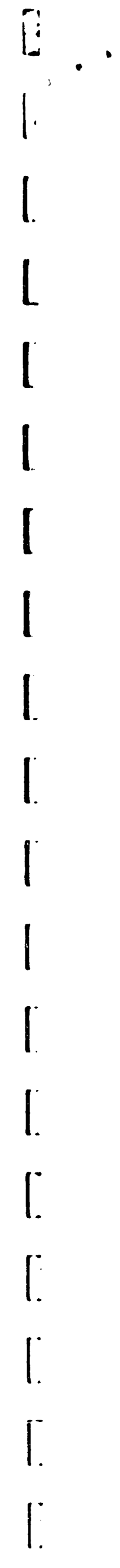

Attachment 2

Agenda for the Workshop on Life Extension Studies

New Delhi, India

February 27, 1992 


\section{POWER FINANCE CORPORATION LTD.}

\section{WORKSHOP ON LIFE EXTENSION STUDIES}

FEBRUARY 27, 1992

\section{VENUE : LE MERIDIEN BOTEL, JANPATH, NEW DELAI-110001}

\section{PROGRAMME SCBEDDLE}

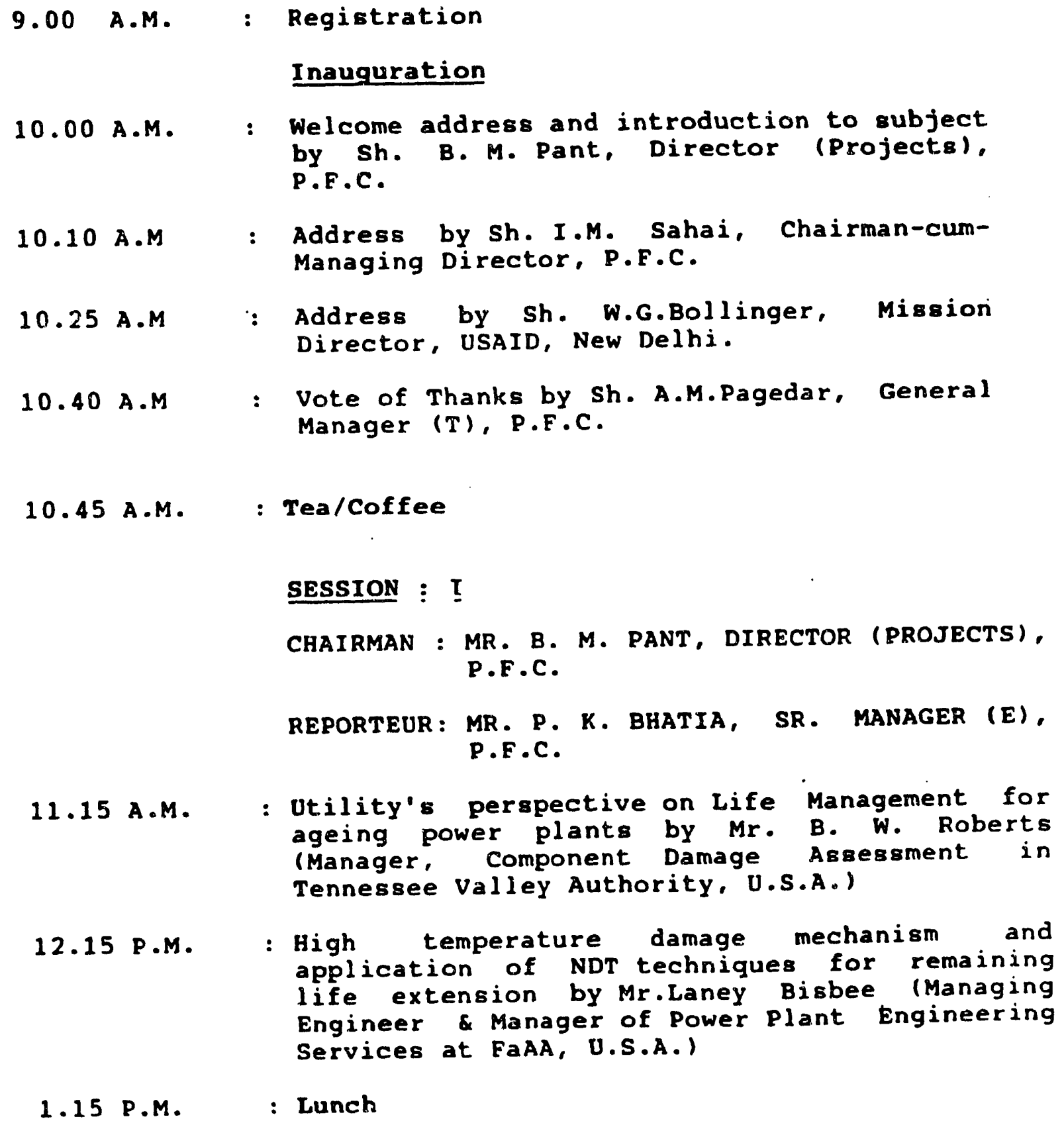

11.15 A.M. : Utility's perspective on Life Management for ageing power plants by Mr. B. W. Roberts (Manager, Component Damage Assessment in Tennessee Valley Authority, U.S.A.)

12.15 P.M. : High temperature damage mechanism and application of NDT techniques for remaining life extension by Mr.Laney Bisbee (Managing Engineer \& Manager of Power Plant Engineering Services at FaAA, U.S.A.)

1.15 P.M. : Lunch 


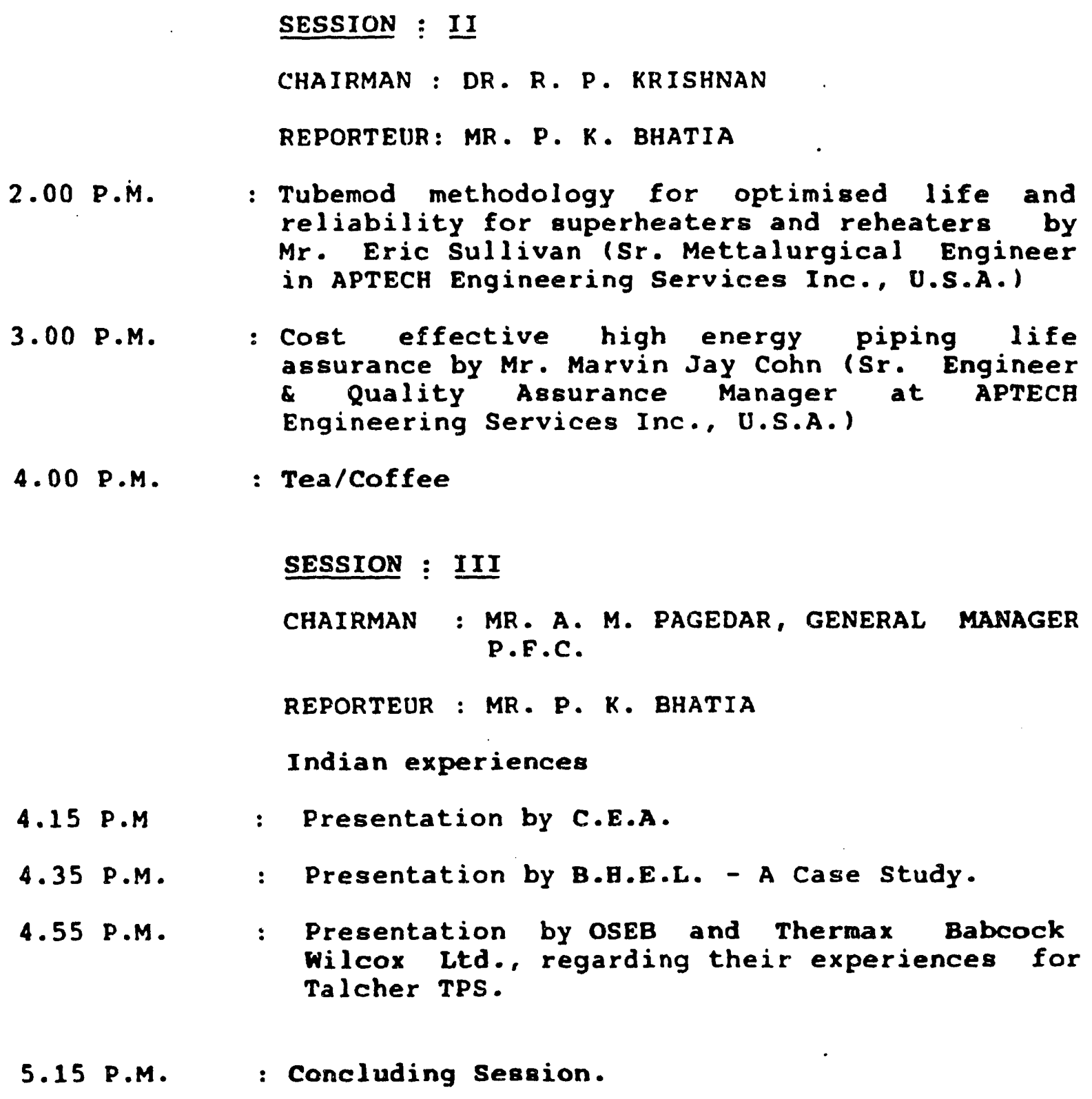
assurance by Mr. Marvin Jay Cohn (Sr. Engineer \& Quality Assurance Manager at APTECH Engineering Services Inc., U.S.A.)

4.00 P.M. : Tea/Coffee

SESSION : III

ChaIRMAN : MR. A. M. PAGEdAR, GENERAL MANAGER P.F.C.

REPORTEUR : MR. P. K. BHATIA

Indian experiences

4.15 P.M : Presentation by C.E.A.

4.35 P.M. : Presentation by B.H.E.L. - A Case Study.

4.55 P.M. : Presentation by OSEB and Thermax Babcock Wilcox Ltd., regarding their experiences for Talcher TPS.

5.15 P.M. : Concluding Session. 
$1 !$

List of Attendees at the Workshop on Life Extension Studies New Delhi, India

February 27, 1992 


\section{POWER FINANCE CORPORATION LTD}

WORKSHOP ON LIFE EXTENSION STODIES OF TAERMAL POWER STATIONS

IN TECANICAL COLLABORATION WITH DSAID

27TB FEBROARY, 1992

NAME OE TEE PARTICIPANTS

ORGANISATION
MSEB
KPCL
OSEB
WBSEB
UPSEB
HSEB
MPEB
GEB

MEMBER

Mr. P. Kama lakumar

Mr. R. Thimma

Mr. D. Y. Ghanekar

Mr. S. D. Mahajan

Mr. P. G. Chavan

Mr.A. R. Deshpande

Mr. R. D. Chalke

Mr. K. Gururajarao

Mr. A. S. Nadgir

Mr. R. P. Mohapatra

Mr. S. N. Ghosh

Mr. S. K. Sikder

Mr. Dipak Ganguly

Mr. Shyam Sunder

Mr. B.P. Keshri

Mr. Marathe

Mr. C.P.Pandey

Mr. K.P.B.Sinha

Mr. D.M. Maniar

Mr. R.R. Thakkar

Mr. O. P. Verma

Mr. D. L. Gulati

Mr. T. C. Gupta

Mr. P. Kumar

Mr. R. D. Rishi
DESIGNATION

C. E. (Gen.)

Exec.Engineer (R\&M)

Dy . C. E, Nasik

DY. C. E, Koradi

S.E., Paras

S.E., Bhusawa l

Dy.Ex.Engr, Hqtrs.

S. E. (Elect.)

Exec. Engr. (Elect)

Gen.Supdt . (TTPS)

Manager (E), (TTPS)

Gen. Supdt, BTPS

S.E. (Thermal Plg.)

S.E. \& Resident officer

S.E. (R\&M)

S.E. (Ren), Satpura

E.E. (Ren), Korba(E)

C.E. (Ren)

S.E. (REM)

E.E. (Dhuvaran TPS)

S.E. Panipat

S.E., Faridabad

Dy.Sec. (Gen.) , Hgt rs

Director, Monitoring

Exec. Engr. 


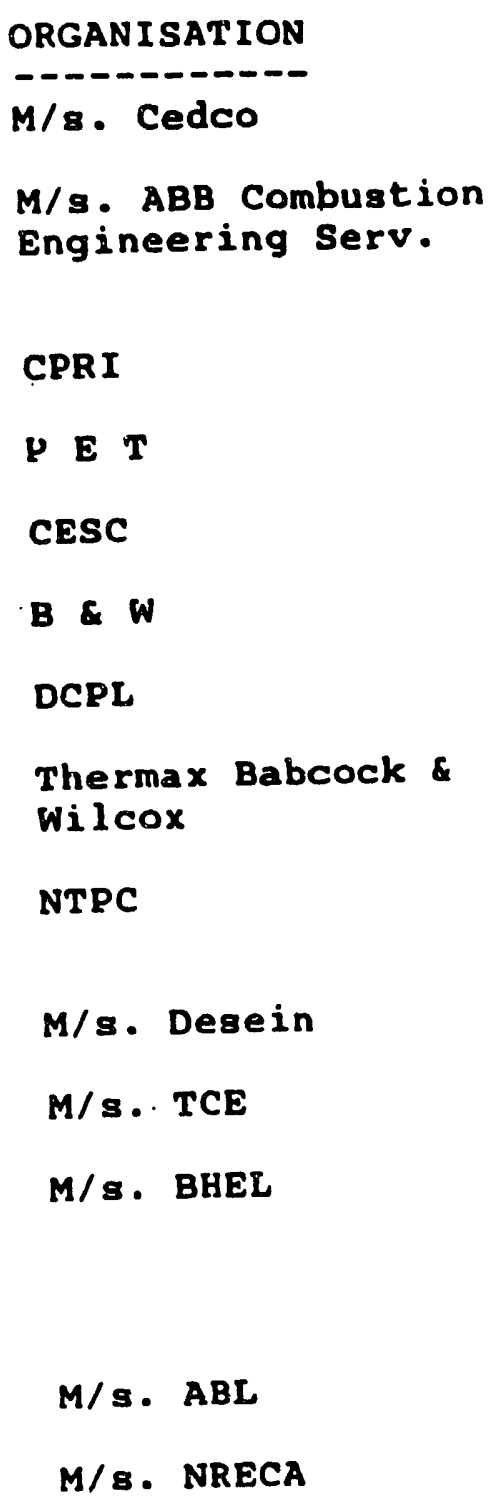

MEMBER

Mr. N.P. Hanagodu

Mr. G. H. Buote

Mr. B. H. Narayan

Mr. A. K. Sah

Mr. M. K.Dutta

Mr. B. R. Ghosh

Mr. S. R. Shome

Mr. Jack Treier

Mr. P.I. Sudhir

Mr. Chandan Roy

Mr. G. Bandopadhya

Mr. C. L. Gupta

Mr. Vikram Wadhwa

Dr. Abbi

Mr. S.C. Angrigh

Mr. Gaurishankar

Ur. Bhave

Mr. R. Natarajan

Mr. Ashok Ahuja
DESIGNAT ION

Dy. Manager (Power)

Director (Power)

K.T.P.S.

Engg. Officer

Exec. Chairman

Manager

Wholetime Director

Director

G.M. (Engineering)

Manager - Marketing

D.G.M.(OS), CC Manager (RD), CC

Chief Engineer

Project Engineer

S. M. (PEM)

Sr. Manager

D.G.M. (R\&D)

G. M. (Marketing) 
ORGAN I SAT ION

USAID

M/s. CEA

M/8. ORNL

M/8. N.P.C

D.N.C.E.S.

SPEAKERS

TVA

APTECH

APTECH

Failure Analysis

Associates
MEMBER

Mr. W. G. Bollinger

Mr. Steve Mintz

M.r. John Grayzel

Mr. N. V. Seshadri

Mr. Robert Blumberg

Mr. N.S.R. Rao

Mr. K. Natarjan

Mr. K.S. Chaube

Mr.H.C. Narula

Mr. Y. Rao

Dr. R. P. Krishnan

Mr. V. Raghuraman

Dr. J. Gururaja

Mr. B. W. Roberts

Mr. Eric Sullivan

Mr. Marvin Jay Cohn

Mr. Laney Bisbee
DESIGNATION

Director

Dy.Mission Director Director, Technology Development Enterprise Energy Projects officer, TDE

Energy Management Advisor, TDE

C.E. (TRM)

Director

Director

Director

Dy. Diretor

Dy.Director

General (MS)

Advisor 
l.

APPENDIX E 


$$
\begin{aligned}
& \text { REPORT OF TRAVEL TO INDIA } \\
& \begin{array}{c}
\text { March } 7-18,1992 \\
\text { by }
\end{array}
\end{aligned}
$$

E. David Daugherty and Chao-Ming Huang

Tennessee Valley Authority

\section{ITINERARY}

Date

March $7-9$

March 10

March 11

March 12

March 13

March 16

March 17

March 18

\section{Event}

Travel to New Delh1. India

Meetings with PFC and BHEL

Meetings with PFC and NTPC

Meeting with PFC

Meeting with USAID

Meeting with PFC

Meeting with Lurgi, Germany

Travel to United States 
REPORT OF TRAVEL TO INDIA

March 7-18, 1992

by

E. David Daugherty and Chao-Ming Huang

Tennessee Valley Authority

\section{PURPOSE}

Mr. Daugherty and Dr. Huang visited India and net with The Power Finance Corporation (PFC), National Thermal Power Corporation (NTPC), Bharat Heavy Electricals Limited (BHEL), and the United States Agency for International Development (USAID) mission to discuss and develop a specific strategy for implementing the condition assessment and life extension component of the Energy Management Consulting and Training (EMCAT) program and to conduct preliminary dialogues concerning TVA's technical assistance in OnLine Diagnostic Monitoring System (OLDMS) and environmental control technology.

\section{EXECUTIVE SURPARY}

This effort was undertaken at the request of the Pittsburgh Energy Technology Center (PETC) of the United States Department of Energy (USDOE) as part of the Alternate Energy Resources Development (ARRD) program sponsored by USAID and the Government of India (COI). The overall coordination of the program is being provided by Oak Ridge National Laboratory (ORNL). After numerous discussions and deliberations, a preliminary draft of work statement for "Model Studies for Coal-Fired Power Plant Condition Assessment and Remaining Life Estimation" under the recently initiated USAID/COI MMCAT program was completed. This document outlines the objectives, overall approach, suggested participating organizations, implementation strategies, specific tasks, project schedule, budget requirements, and benefits to all participants. Two model studies specifically aimed at developing and establishing the domestic capability of India in condition assessment and life extension of power plants are being proposed under ExCAT. A preliminary approach for technical assistance by TVA on the OLDMS was also tentatively agreed by TVA and PFC.

\section{IRAVEL SUMALARY}

Meetine with PRC and BHEL. Ney Delhi

Mr. Daugherty and Dr. Huang, along with R. P. Krishnan, ORNL, wet with B. M. Pant, Director, PFC, and R. K. Gupta, Deputy General Manager, PRC, on March 10 to conduct general discussion on the EMCAT program, to firm up the agenda for the meetings with various $C O I$ agencies, and to reach a common understanding of the goal and expected results of this visit. Mr. Daugherty aiso presented an overview of TVA' Research and Development (R\&D) program to 
Mr. Pant, Mr. Gupta, and other PFC staff. Selected ongoing projects at TVA in environmental contral teshnology, power plant performance and availability irprovement, advanced power generation, generation and storage, bioenergy, transmission system reliability, power quality, and environmental effects were highlighted in this presentation.

A visit to the BüEL corporate offices was also made with K. Ramakrishnan, Director of Engineering, Research and Development, BHEL, to learn about BHEL's capabilities and to explore its interest in participating in the EMCAT program. BHEL has excellent facilities and bighly skilled technical staff members tho have been trained to perform plant condition assessment, maintenance, and repairs. Its experience and data base will be very valuable in implementing the nodel studies. Mr. Ramakrishnan confirmed BHEL's comitment to life extension projects in India and expressed a keen interest in participating in the model studies.

Meeting with Pi" and NTPC. New 's=lhi

IVA and ORNL representatives visited PFC again on March 11. This meeting centered on OLDHS and environmertal control technology issues. Dr. Huang made a presentation of TVA's R\&D projects in these areas. In the OLDMS area, detailed presentation and discussion included online real-time monitors for heat rate, heat rate losses, boiler perfcrmance, turbine performance, condenser performance, high-pressure feeduster heater performance, boiler tube leak, sag formation, and continusus vibration of rotating equipment. The unique and advantageous features oi the TVA-developed microcomputer-based system, such as the use of achievable rather than design target beat rate, a special method for accurately measuring condenser waterflow, the use of special differen'ial-pressure ratios for accurate indication of zondenser fouling, the vay the various monitors are integrated into a single system, and the flexibility of the system and its adaptability to a customer's specific requirements vere emphasized. Although the software and system design are standardised, the displays may be changed to $s$ it the particular requirements of a plant. Systems with different combinations of monitors have been installed at several TVA plants to meet specific plant requirements. significant cost savings are being realized through improvements in unit heat rates and through timely scheduling of unit outages for equipment services and/or repairs during low power demand while avoiding extended equipment damages.

On environmental control technology, Dr. Huang presented the test results from TVA's 10-MW spray dryer/electrostatic precipitator (SD/ESP) and the 1.2-MW selective catalytic reduction (SCR) pilot plants. The most significant resulis from the 10-MW SD/ESP project are that addition of atll amount of calcium chloride to tl a lime/fly ash slurry dramatically improved the $\mathrm{SO}_{2}$ removal in the SD and the particulate removal in the ESP. High removal e.ficiencies, 95 percent for $\mathrm{SO}_{2}$ and 99.98 percent for particulates, are achievabie with Ca/S stolchiometric ratio of 1.3-1.4 at 18 degrees of approach-to-saturation cemperature for medium-sulfur (2.7-3.0 percent sulfur) 
coal. This makes the SD technology technically and economically competitive with wet scrubbers for medium-sulfur coal applications. For low-sulfur coal, SD is more economical than wet scrubbers. Limited tests indicate that the SD/ESP remove up to 70 percent of mercury from the flue gas.

For the SCR project, IVA's experience with two different catalysts was discussed. A titanium dioxide-based catalyst withstood sulfate-induced degradation better than a vanadium-based catalyst. The former also performed better, achievirag $\mathrm{NO}_{x}$ reduction of $92-95$ percent at $\mathrm{NH}_{3} / \mathrm{NO}_{x}$ ratio of 0.95 and $\mathrm{NH}_{3}$ slip (escape of $\mathrm{NH}_{3}$ with flue gas through the reactor) of less than $5 \mathrm{ppm}$, which is generally accepted as the maximum allowable slip. Serious catalyst pluggages have been encountered, partly because of $\mathrm{SO}_{3}$ formation and condensation and partly because of numerous startups and shutdowns. Improvement in the startup and shutdown procedures and installation of sootblowers have reduced these problems.

TVA's plans for testing at the 10-MW pilot plant on the ADVAnced SiliCATE (ADVACATE) process and the gas suspension absorption process (AirPol, Inc., under the DOE Clean Coal Technology III project) were also discussed. It was also mentioned that IVA is placing increased emphasis on the control of air toxics emission and will be testing for air toxics in the dry flue gas desulfurization (FGD) process. TVA is also planning to test wet ESPs downstream of a wet scrubber to determine the effectiveness of this combination in reducing fine particulate and acid mist emissions, plume opacity, and air toxics.

R\&D's involvement in the low-NO $\mathrm{N}_{x}$ burner program now under way at TVA was discussed briefly. R\&D performs pre-installation baseline and postinstailation emission monitoring. R\&D also provides advice on measuring burner air/fuel ratio balancing and fine tuning the boiler for baseline emission monitoring.

After the meeting at PFC, a visit was made to NTPC. Attendees at the meeting were R. Shahi, Director of Operations, NTPC; A. Palit, General Manager of Corporate R\&D, NTPC; and representatives of IVA and ORNL. The purpose of the aeeting was to learn about the resources and technical skills guaifable at NTPC for conducting the life assessment model studies under EMCAT and to explore their interest in participating in these studies. NTPC maintains a very extensive data base on operation and maintenance problems encountered in their plants. They also have inhouse capability in component condition assessment. NTPC has made decision to further develop their inhouse capability to be self-sufficient in solving many of the component-associated problens in their plants. NTPC now generates about 11,000 MW of electricity from coal-fired power status. This figure will be $30,000 \mathrm{MW}$ by the turn of the century (roughly a third of the total power generated in the county from coal-fired utilities). NTPC's participation in the EMCAT program should complement its own inhouse program and should be beneficial to both programs. NTFC's interest in EMiCAT was evidenced by its readiness to procure hardware and diagnostic equipment from their own funds and by Mr. Shahi's pledge to provide full support of the R\&D and plant employees. Mr. Palit conducted a tour of NTPC's existing testing laboratory facilities. The NTPC laboratory staff presented its capabilities and results of ongoing work. 


\section{Keetine with PFC. New Delhi}

On March 12, TVA and ORNL representatives met with Mr. Gupta to develop the first draft of the work statement for the plant condition assessment and life extension program. It was decided that two model studies should be performed at two Indian utilities. The following items were discussed extensively: overall objective, specific objectives, overall approach, orgnizations expected to participate in the model studies, implementation strategies, implementation and specific tasks including assignment of organizational roles and responsibilities, project duration, cost breakdown and total cost, and benefits to participating organizations.

Training of Indian engineers at TVA power plants for condition assessment and life extension as part of this program was discussed. In the past, TVA has conducted comprehensive formal training in power plant operation and maintenance for developing countries. Mr. Daugherty indicated that he would check with TVA's management to see whether IVA would be interested in reactivating the training program. He also suggested that an excellent facility for training the Indian engineers on nondestructive testing (NDT) techniques in the U.S. is the Electric Power Research Institute's NDT Center in Charlotte, North Carolina; and he volunteered to inquire about the details concerning arrangements for such training for the Indian engineers. It was suggested that the ultimate goal be to develop India's domestic capability to provide NDT training for their engineers.

TVA's assistance in OLDMS was also discussed. PFC is particularly interested in TVA's assistance in training Indian engineers in the component and system design of the OLDMS and in setting up a prototype OLDMS in an Indian utility. Some options for training which were discussed include one-week visit to TVA's Kingston Diagnostic Center for familiarization of various monitors and the working of the system and another week to TVA plants for observation of actual operation and utilization of the OLDMS. For setting up a prototype, TVA engineers will be onsite at a selected Indian power plant to work with Indian engineers. Ideally, before arrival of TVA engineers, all the required sensors and wiring should be installed.

Some NTPC power plants have installed monitors, such as boiler tube leak detectors and 1 lag monitors. It was suggested that, to keep the cost of the prototype system at a minimum, the selected plant should already have as many existing instruments and monitors as possible.

Despite TVA and PFC's mutual interest in this subject, the priority in EMCAT is the power plant condition assessment and life extension. A specific implementation plan for OLDMS will be worked out with PFC at a later date.

Visit to the USAID Kission. New Delhi

TVA and ORNL representatives and Mr. Gupta visited the USAID mission on March 13 to meet with J. Grayzel, N. V. Seshadri, and R. Blumberg, a consultant to USAID. The objectives of the meeting vere to brief the mission on the progress that had been made on the planning of the life extension model studies and to seek their input. The preliminary statement of work was 
discussed, and USAID indicated that it was acceptable. Contract negotiations with USDOE will be initiated by USAID once PFC requests the mission to proceed on this activity.

Yeeting at PEC, Ney Delhi

TVA and ORNL representatives and Mr. Blumberg met with Mr. Pant and Mr. Gupta at PFC on March 16 to finalize the work statement for the model studies. Most discussions and the revision of the draft concerned the organizational roles and responsibilities and the cost breakdown. It was agreed that Mr. Blumberg would handle the preparation and distribution of the final version of the work statement.

Mr. Daugherty pointed out that activities in OLDMS and environmental control R\&D and emissions monitoring, which are of interest to PFC, come under R\&D. Therefore, TVA's assistance in these areas would be straightforward. However, the activities in life extension fall under the Generating Group in TVA. Therefore, the role TVA will be playing in this particular program will need to be coordinated with and approved by the senior management of that group. Mr. Daugherty will coordinate with the Generating Group once a final copy of the work statement is received.

Meeting with Lurgi AG. Frankfurt, Germany

Mr. Daugherty and Dr. Huang stopped at Frankfurt and visited Lurgi on their way back to the United States. The purpose of the visit was to get an update on Lurgi's integrated coal gasification/combined cycle (IGCC) power generation and circulating fluid bed flue gas desulfurization (CFB/FGD) technologies. Claus F. Greil made a presentation of the IGCC program, and Harald Sauer made a presentation of the CFB/FGD program. Dr. Sauer also provided a tour of the CFB/FGD installation at the Opal Automobile Manufacturing Plant south of Frankfurt.

\section{CONCLUSION}

Mr. Daugherty and $\mathrm{Dr}$. Huang had an extensive exchange of information with PFC, NTPC, and BHEL in power generation in general and in life extension, OLDMS, environmental control technology, and emissions monitoring in particular. A good understanding of the areas of mutual interest and technical capabilities was obtained from this visit. The primary $80 a l$ of the trip, which was to lay out and agree upon the detailed strategy for implementing the plant condition assessment and life extension program under BMCAT, has been accomplished. The door has been left open for TVA's assistance in areas other than the life extension program which are of interest to India.

PFC has a firm commitment to the EMCAT program and is approaching this program with superb professionalism. Everyone involved showed great enthusiasm and spirit of cooparation. There are many opportunities in coal technology for the United States and Indian organizations. With full cooperation of all 
organizations involved, this program can bring to India the domestic capability in plant life extension. The support being provided by PETC and ORNL in the coal projects in India is looked upon in a very positive manner in USAID and the other key organizations in the power sector in India. Continued - upport of USDOE and ORNL is recommended in the life extension model study projects in India. Opportunities for technology transfer and joint ventures in the private sectors in both countries exist and should be pursued. USDOE, ORNL, and TVA can assist in these endeavors. 

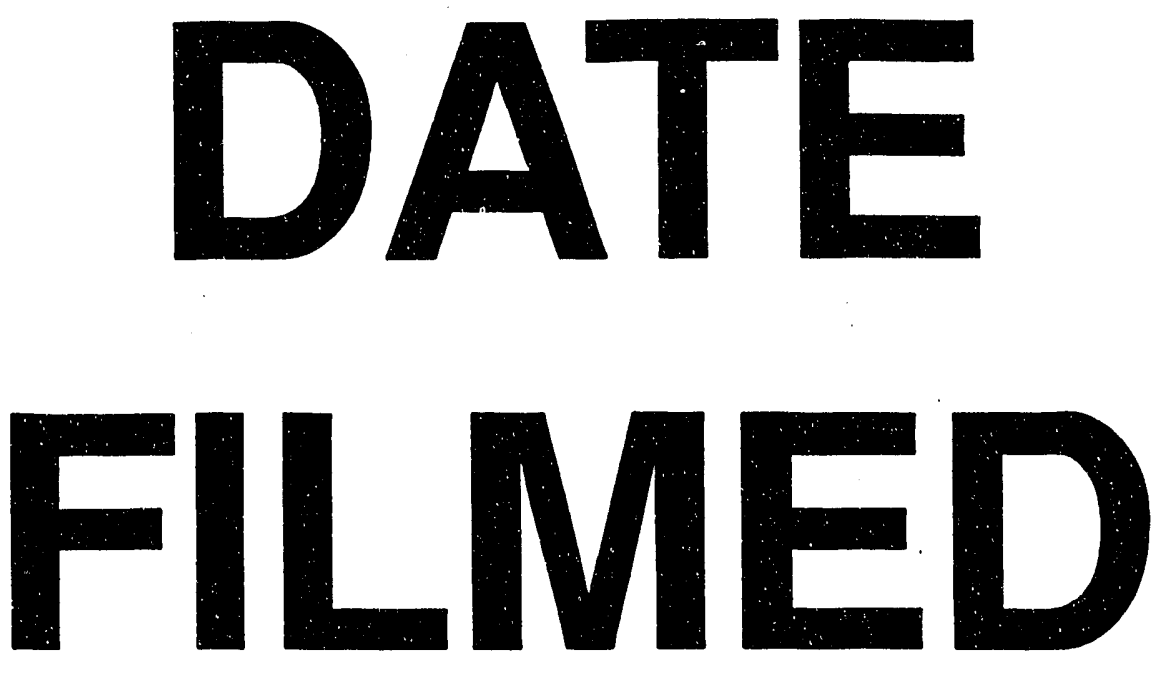

$$
8 / 23 / 93
$$
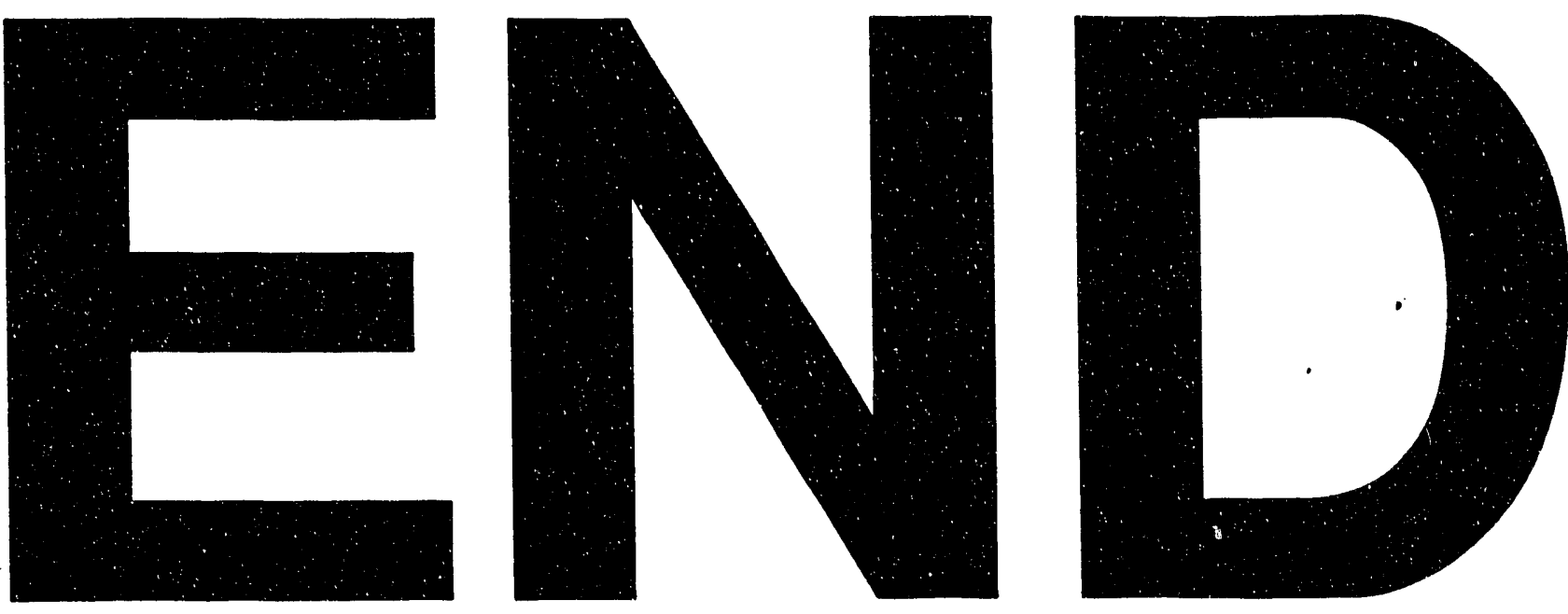
